\title{
Short-Term Assessment of Retreating vs. Advancing Microtidal Beaches Based on the Backshore/Foreshore Length Ratio: Examples from the Basilicata Coasts (Southern Italy)
}

\author{
Sergio G. Longhitano \\ Department of Sciences, Basilicata University, Potenza, Italy \\ Email: sergio.longhitano@unibas.it
}

Received 28 December 2014; accepted 22 January 2015; published 26 January 2015

Copyright (C) 2015 by author and Scientific Research Publishing Inc.

This work is licensed under the Creative Commons Attribution International License (CC BY).

http://creativecommons.org/licenses/by/4.0/

(c) (i) Open Access

\begin{abstract}
A straightforward conceptual method is proposed to quantitatively assess the seasonal-scale tendency of retreatment or advancement on microtidal beaches by using the backshore/foreshore length ratio. This method is based on measuring the cross-shore profile of a beach when it passes through the "transitional state" that separates the high- from the low-energy season, period during which the morphological characteristics of the beach tend to its equilibrium profile. In order to obtain real measurements of backshore $(B)$ and foreshore $(F)$, the definition of the limits bounding these two important components in subaerial beaches is reviewed and discussed. The approach based on the measurement of the $B / F$ length ratio assumes that foreshore and backshore have equivalent lengths in beaches that approximate to their state of morphodynamic equilibrium $(B / F$ 1). A backshore length exceeding the foreshore length is indicative of a state of beach recession, with a $B / F$ length ratio $>1$. When the foreshore length is greater than the backshore length, the shoreline is advancing or, alternatively, it is developing in a state of morphological confinement, i.e. due to the presence of a sea cliff, with a $B / F<1$. This practical method is then tested against 36 sand and gravel microtidal beach profiles measured along the coasts of Basilicata, in southern Italy. The various "beach states" are summarised into seven classes (I-VII), each identified from specific value intervals of the $B / F$ length ratio.
\end{abstract}

\section{Keywords}

Beach Profile, Subaerial Beach, Backshore, Foreshore, Equilibrium Profile 


\section{Introduction}

Field analyses carried on modern beaches are usually retained crucial in detecting their morphodynamic status, in terms of equilibrium and disequilibrium [1] [2]. Such analyses can be easily obtained through expedited measurements of the linear dimensions of each single zone of a beach, for both subaerial and subaqueous environments [3]-[5].

In either sand and gravel beaches, the subaerial sector represents the zone where the signatures of the recent hydrodynamic activity of the sea can be easily recognised by detecting a series of distinctive components, including the backshore and the foreshore length. The linear extent of these sub-environments reflects faithfully the hydrodynamics that has affected a beach in recent times: backshore and foreshore express the quantity of sediment that is moving on a beach in relation to the natural forces that dominate that beach [6].

In the last fifty years, a number of different conceptual models contributed to delineate and differentiate subenvironments in modern microtidal subaerial beaches, distinguishing internal zones, usually dominated by the wind action except during extreme storms, and external zones of a beach, where the wave dynamics prevails.

However, although the models showing sub-environment partitioning of the subaerial part of a beach are numerous and useful, the distinction between backshore and foreshore still remains confusing and the boundary between these two important sub-environments is often arbitrarily chosen and placed without any physical evidence.

In this work, a conceptual model is applied to the study of the coastal dynamics in order to assess quantitatively the rate of retreatment/advancement of microtidal beaches by using a backshore/foreshore (B/F) length ratio. This method can be practically applied to detect short-term beach variations, measured once a year during the transitional or "sweep period" of a beach, possibly during the spring or fall (April-May in the North Temperate Zone, and October-November in the South Temperate Zones). During this interval, a beach previously subjected to high-energy storms, tends to re-establish the sediments lost, changing its bi-dimensional shape towards an equilibrium profile [7]. This transition is the expression of high-frequency shoreline changes during a longer-term pattern of advancement or retreatment [6].

The importance of the linear dimension of the backshore and foreshore measured in different coastal settings, where the effects induced by the tidal range are negligible at the coast, is then discussed and referred to the their state of preservation at the time of the measurement.

The beach examples considered in this study are from the Tyrrhenian and Ionian shorelines of the Basilicata, in southern Italy. Along these microtidal coasts, a number of different beach types have been measured and studied in order to document and compare backshore and foreshore zones with different features.

\section{Beach Terminology, Environments and Sub-Environments}

In a cross-shore profile, the beach is conventionally divided into zones on the basis of morphological, hydrodynamic and sedimentary processes [6]. The terms used to define these zones differ slightly between geomorphologists, sedimentologists or engineers (e.g., [8]). A general and very well known scheme is shown in Figure 1. According to this model, a beach can be subdivided into a subaerial and subaqueous sector. (1) The subaerial

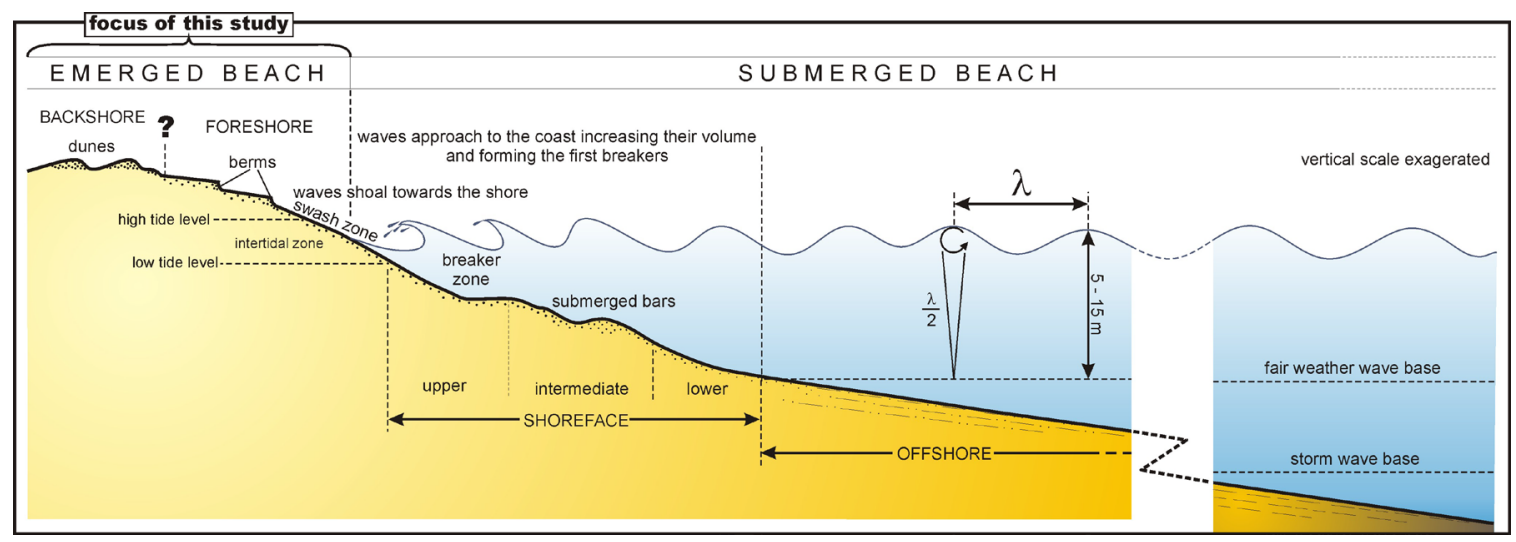

Figure 1. Cross-shore (bidimensional) beach partitioning showing subaerial (focus of this study) and subaqueous environments and sub-environments (modified from [9]). 
sector coincides with the area mostly used for recreational activities that extends no farther seaward than the shoreline, having a width that varies with changing water level. This segment of the beach is usually divided into two main sub-environments: backshore and foreshore. The part of the beach which is subject to variations in water line depending on the correspondent tidal range (micro-, meso- or macrotidal), is termed intertidal zone. (2) The subaqueous sector of a beach is that zone lying constantly under the water line and is consequently subject to the influence of the water motions (fair-weather and storm waves, alongshore currents and tides). This sector is generally thought as nearshore. The nearshore comprises shallow water environments in which waves strictly interplay with the sea-floor and clastic sediments. The nearshore includes the shoreface directly attached to the subaerial beach and where waves break, whereas deeper environments are termed offshore (Figure 1) or inner to outer shelf [9], depending from the wave base level during the fair-weather and storm conditions (Figure 1). The present paper will focus only on the subaerial sector of the beach and on the importance of its relative sub-environments.

\subsection{Backshore}

According to the most common and used definitions (e.g., [7]-[10]), the backshore is the more landward and elevated part of the beach, which is typically a near-horizontal to gently landward-sloping surface. The backshore is generally not affected by wave run-up except during storm events of extreme energy. For this reason it typically represents the dry sector of the beach [11]. "Back beach" or "backshore beach" are definitions that were also adopted and intended to discriminate the upper shore zone of subaerial beaches that is beyond the advance of the usual waves and tides [12]-[14]. These definitions are valid only for wave-dominated shorelines, where the wave motion is the dominant hydrodynamic influence on the beach morphology and on the sediment distribution [15] [16]. On the contrary, fluvial- and tide-dominated shorelines are typically subject to other different hydrodynamics with the wave influence irrelevant [17]. Other models define the backshore as the zone of the beach that lies above the water line [6].

The landward limit of the beach is generally marked by a change in the sediment grain size and in the morphology. This sub-environment of the subaerial beach can include aeolian dunes. Sediments are very well sorted, having a dominant grain size from medium to fine sand with uni-modal distributions [18]. Clasts can be organised to form small wind ripples in the more external sector of the backshore (foredune) and fields of barcanoid to straight-crested dunes in the most internal sector [16].

\subsection{Foreshore}

The foreshore is the sector of the beach that lies in contact with the water line and, therefore, it is directly influenced from the wave hydrodynamics [16]. From a morphological viewpoint, it is represented by a seaward-inclined surface interrupted by a series of erosional berms and scarps. These physical elements are near-vertical incisions caused by wave action during higher water levels associated with seasonal variations of energy (e.g., swash berm, storm berm, ...). A beach profile is shaped by swash and backwash as waves break upon the shore, and varies in response to wave conditions. Constructive waves shape convex-up profiles, often with one or more swash-built berms (ridges or beach terraces) parallel to the coastline, while erosive waves cut scarps and shape concave-up profiles [7].

Generally, this sector of the beach includes the swash zone (Figure 1) which is characterised by sediment with a marked bimodal grain size distribution in sand beaches. The presence of medium to coarse, very well sorted sand with pebbles indicates sediment transport and deposition during high-energy marine events [19]. Sediments can be organised into high-angle, landward-dipping cross lamination as consequence of wave run-up to the beach and low-angle, seaward-dipping cross lamination in the swash zone, as result of wave swash and backwash movements [11].

\section{Methods}

\subsection{Beach Profile Measurement}

The recognition of the limit that separates the backshore $(B)$ from the foreshore $(F)$ is here considered crucial in order to identify the real linear dimension of a beach profile, whose physical components are, in turn, directly dependent on the state of equilibrium or disequilibrium during periods of shore advancement or retreatment [20]. 
In order to identify a beach shape that well approximates to the reality, beach profiles can be surveyed by using a level and graduated stadia rod along profiles set up normal to the shore [21]-[23]. In the last decades, this method has been substituted with more rapid and detailed techniques of acquisition, such as the use of an electronic theodolite distance measurer, interfaced with a differential GPS with a vertical accuracy of $\pm 2-3 \mathrm{~cm}$. Alternatively, a wheeled vehicle designed to register altitude variations along a beach transect can be utilised. Also remote sensing techniques, such as X-band radar, airborne laser terrain mapping (ALTM) and light detection and ranging (LIDAR), can be alternatively employed (e.g., [24]-[26]).

The profile of the subaerial beach that is measured using these techniques extends from the base of the swash berm (coincident with the mean low tide level and, therefore, lying below the water line) landwards up to the back dune zone [27] [28], where usually alluvial sediments occur (except for multiple chenier coastal systems). In case of high, cliffed coasts, the internal limit of the beach corresponds with the base of the sea cliff.

Usually, repeated profile surveys should be acquired at constant time interval of a few months (e.g., every three-four months during each season or, more simply, one during the summer and one during the winter) in order to determine patterns and rates of changes on a beach [29]-[31]. These patterns are indicative of short-term beach adjustments, which are thought to be the high-frequency variations of longer term shoreline changes ([6]; p. 290). However, during the time span elapsing between the high-energy and the lower-energy season ("transitional state" in Figure 2), a beach undergoes morphological change from an under-supplied state, when sediments are removed from high-energy waves (Figure 2(a)), to an over-supplied state, during which sediments return to the beach by the action of fair-weather waves or alongshore currents [6]-[14] (Figure 2(b)). Thus, the real approximation to the equilibrium profile for a microtidal beach can be identified just in the middle of this cyclic continuum of seasonal duration (Figure 2(c)). The symmetry of the "sweep zone" described in Figure 2 is representative of stable beaches (neither advancing nor receding) after a seasonal cycle of change (Figure 2(c)).

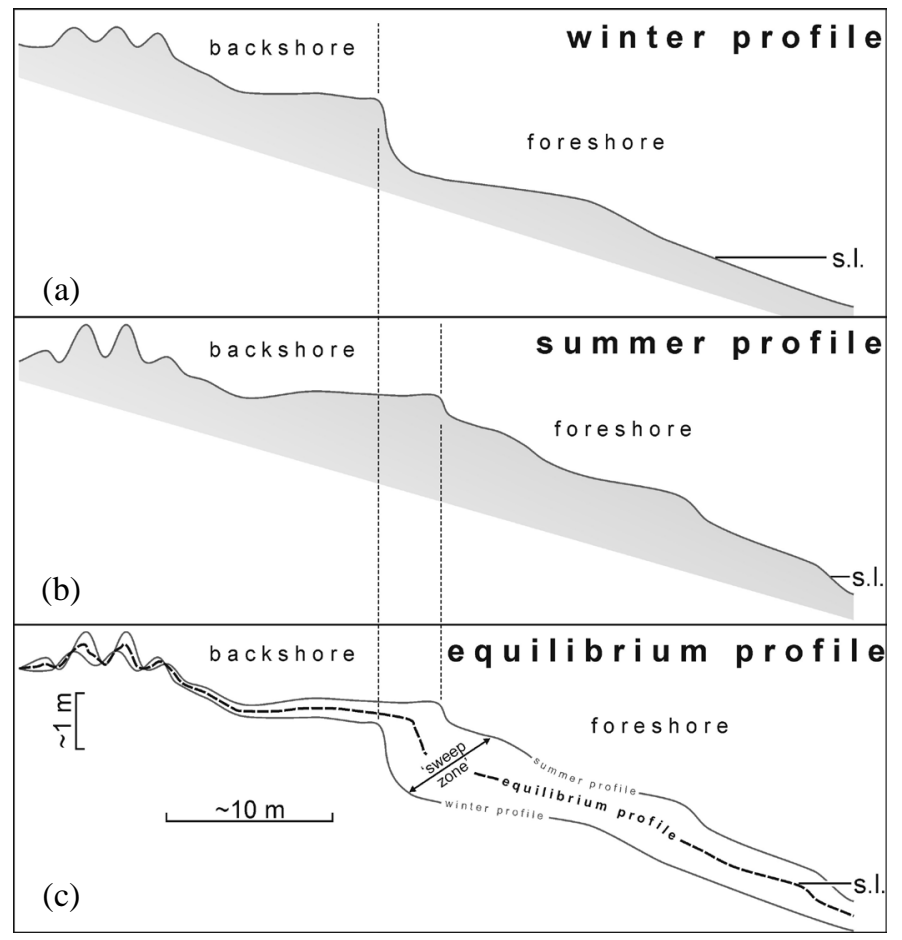

Figure 2. Cross-shore profile representative of a stable beach during (a) the winter and (b) the summer (sea level is assumed to be stationary). The comparison between these two profiles results in an intermediate beach shape (c), that can be approximated to the equilibrium profile of that beach. The so-called "sweep zone" corresponds to the space comprised between seasonal endpoints and can be assumed as the bi-dimensional expression of the sediment volume (resulting from subsequent removal and replacement) transported across a beach during one year. 
In beaches affected by a state of general (long-term) advancement or retreating, the sweep zone is asymmetrical, resulting in different linear extension of the physical components of the subaerial beach. Therefore, the representative changing pattern of a subaerial beach can be assessed if a single profile measurement is acquired in proximity of such transitional state. The backshore and foreshore lengths, if properly detected and measured, can be then used as proxy in order to recognise short-term patterns in a changing microtidal beach.

\subsection{The Backshore/Foreshore $(B / F)$ Boundary}

Despite its apparent simplicity, the boundary dividing backshore and foreshore in a subaerial beach is in practice a challenge to identify; indeed, it was differently defined in the past literature according to various types of subdivisions or schemes.

Starting from the $50 \mathrm{~s}$, most of the morphology-based models placed the $B / F$ boundary at the limit of the high water swash [32] (Figure 3(a)). Ottman [33] denominates B and $F$ as "high beach" and "beach s.s." respectively, placing their division at the first berm crest.

Bird [7] [8] shifted this division seawards, down to the medium high tide level (Figure 3(a)), whilst based on
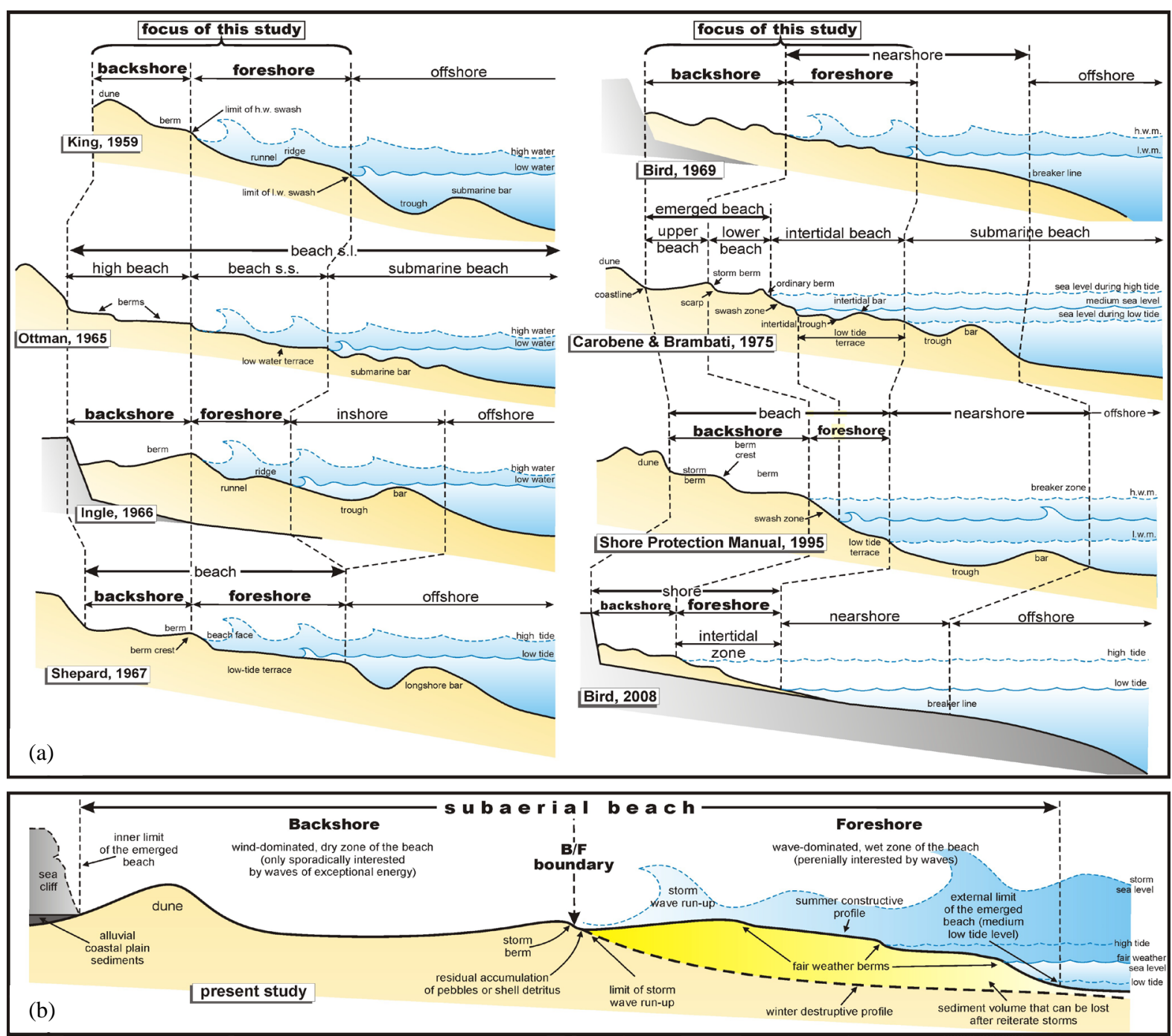

Figure 3. (a) Various beach models illustrating the main differences in the identification of the physical limits bounding the backshore and foreshore; (b) Backshore/foreshore subdivision proposed in this study: The external foreshore limit coincides with the main low tide level, the internal backshore limit is marked by the occurrence of alluvial deposits or a sea cliff. The $B / F$ boundary corresponds with the maximum wave run-up on the beach. 
sedimentological evidences, Walker and Plint [9] retreated the $B / F$ boundary landwards up to the foot of the first foredune (Figure 1).

However, the $B / F$ boundary placed at the first berm, which is produced by the wave erosion to the beach and coincident with the medium high tide level [34]-[38], was successively adopted also in other modern schemes [12] [39]-[41] (Figure 3(a)). Although other similar or slightly discrepant definitions were made in the subsequent decades, the Bird's morphological division [7] seems to have been largely accepted in the most common models used for different purposes.

Taking into account sedimentological, morphological and hydrodynamic features which are easily detectable in a microtidal subaerial beach, a revised beach partitioning and relative limits is thus proposed.

\subsection{Definitions of Backshore and Foreshore Used in This Study}

Based on the most common definitions, the foreshore represents the external part of the subaerial beach which is seasonally subject to the wave run-up (i.e., the maximum vertical extent of wave uprush on a beach [42]-[46] (Figure 3(b)). The landward-advancing capacity of the wave run-up is highly varying, depending on the oceanographic setting of the hosting coast. The series of berms or scarps that can be detected in this part of the beach result from the mechanical action of erosion that the wave front exerts on unconsolidated sediment. If the maximum wave run-up during the most energetic season (usually the winter) is produced along a beach, the point of maximum wave ingression represents the internal limit of that part of a subaerial beach which is directly subject to the wave action. Anomalous or rare storm waves that occur at time scale of a few tens of years or more in the Mediterranean Sea meteorological-driven extreme events are rare or virtually absent, whereas anomalous waves are thought to be of seismic origin [47]-[49], have to be considered as exceptions and thus excluded from this model. The signature of the maximum run-up is recorded by pebble clusters or marine debris along a sand beach (Figure 4(a)), where the morphological expression of the resulting scarp may be erased by the wind deflation or by the human passage during the ensuing periods. On gravel beaches, this limit is usually better preserved and it consists of abrupt variations in pebble shape and/or grain size, often associated with scarps followed by a gently landward-sloping profile (Figure 4(b)).
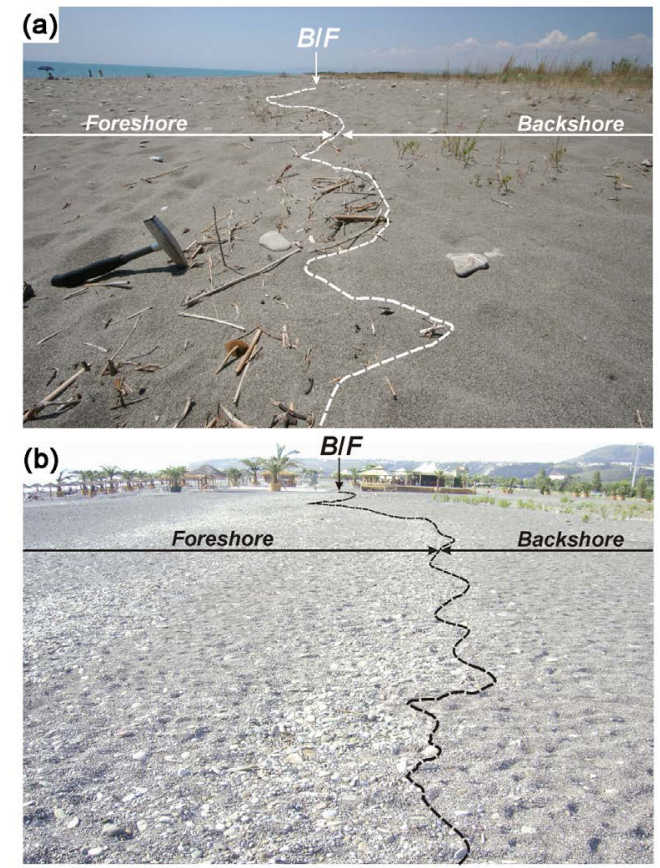

Figure 4. Examples of $B / F$ boundary in a sand (a) and in a gravel (b) beach. In sand beaches, the wave run-up is capable to up rush the foreshore, transporting and accumulating detritus, such as shells or vegetal remains (dashed line). In gravel beaches, the maximum wave run-up is expressed by disc-shaped pebble clusters (note the abrupt grain size "break" on the $B / F$ boundary). 
From this point landwards, the backshore develops. This zone is affected very rarely by waves or can be occasionally inundated by long waves with enough inertial energy to reach this part of the beach. Therefore, since this infrequent condition represents an indirect effect of the wave motion, the backshore can be considered as dominantly subjected to the wind action. In sand beach, this zone usually shows fine and very well sorted sediments, associated with small wind ripples and dunes. Depending on the local geomorphologic setting, a dune field can be characterised by high forms (up to $10-15 \mathrm{~m}$ ), usually covered by typical vegetations. The landward limit of the backshore corresponds with the first alluvial sediments in wide beaches or with the base of the sea cliff in confined beaches [50].

The physical signature marking the limit of maximum wave run-up can be preserved on a beach for weeks or months later after the storm event (Figure 5(a)). Indeed, the subsequent fair-weather sediment restoring tend to fill the concave-up part of a profile, in sand as well as in gravel beaches. The re-fill process usually accumulates a deposit, which lies on, and is attached to, the previous beach profile. The "re-attachment point" (Figure 5(b)) can be easily revealed through a change in the profile shape or through marked grain size differences between previous and subsequent deposit.

\subsection{Backshore/Foreshore Length Ratio $(B / F)$}

The boundary separating backshore and foreshore in a subaerial beach acts as a "balance point" in the distribution of sediment masses (Figure 6). These masses are distributed along the two main counterparts of the beach, which are bi-dimensionally represented from their respective lengths. If the two masses included in the backshore and foreshore are virtually equivalent, the subaerial beach lies in a condition of equilibrium (Figure 6(a)).

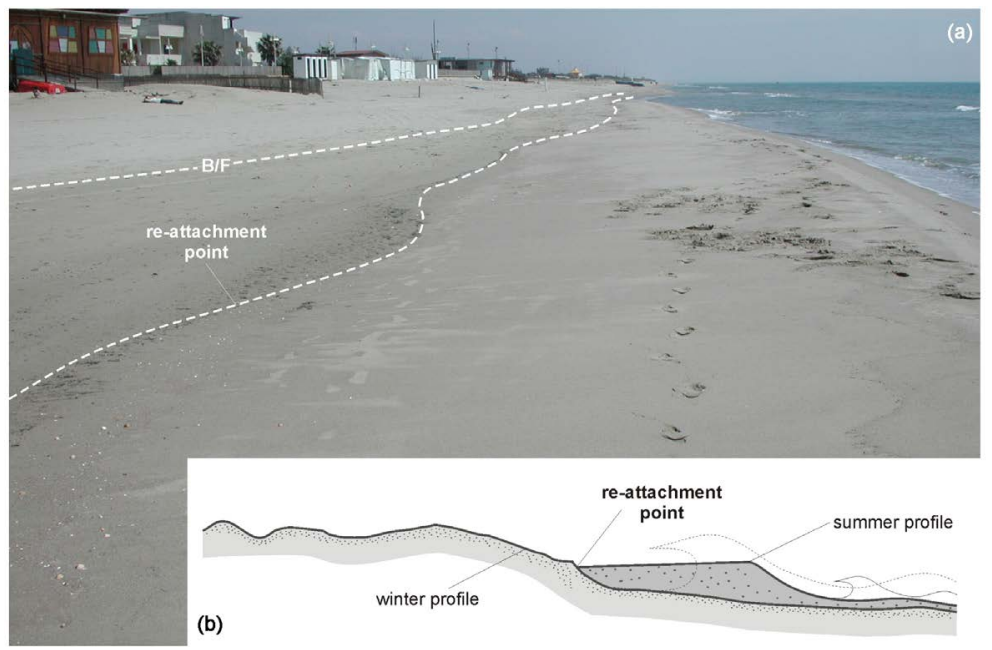

Figure 5. (a) Example of the Metaponto sand beach observed during the "transitional state" from the winter to the summer profile; (b) During this time span, swells re-accumulate sediments on to the previous eroded beach. Note as the re-attachment point does not coincide with the $B / F$ boundary, which represents the maximum wave run-up limit.

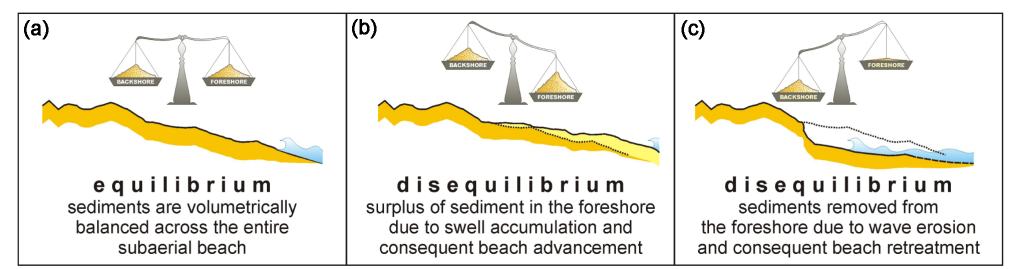

Figure 6. Seasonal variations of sediment masses along backshore and foreshore and their influence on the dimensions of a subaerial beach. (a) Backshore and foreshore are in "balance" when their respective sediment volumes are closely equivalent. If foreshore undergoes swelldriven sediment addition (b) or storm-wave erosion (c), the beach changes its equilibrium condition (in this scheme, backshore sediment volume is assumed to be invariant). 
This condition changes if backshore or foreshore undergo substantial sediment mass variations: e.g., during beach accretion, foreshore length increases as swells accumulate additional sediments (Figure 6(b)); during beach recession, powerful waves deprive foreshore of important sediment volumes (Figure 6(c)). Similar disequilibrium conditions occur when sediment volume decreases in the backshore, e.g. due to erosion of dunes.

Consequently, beaches characterised by a morphodynamic equilibrium condition have backshore and foreshore with lengths roughly tending to the equivalence $(B / F \approx 1$; Figure $7(a))$. In beaches where the backshore linear extent exceeds that of the foreshore, $B / F>>1$ indicates a disequilibrium condition and a short-term (seasonal) state of beach recession and erosion (Figure 7(b)). On the contrary, $B / F<1$ indicates a state of shoreline advancement. Alternatively, a poorly developed or nearly absent backshore points out a condition of geomorphic confinement, induced by the presence of a sea cliff or human buildings (Figure 7(c)).

Therefore, the beach equilibrium $(B / F \approx 1)$ represents a morphodynamic state to which a beach profile tends after periods of repeated storms (winter) or, on the contrary, in absence of them (summer). These intermediate conditions represent "transitional states" that record decreases (beach retreat) or increases (beach accretion) of sediment mass. Consequently, relevant variations in sediment volumes result in backshore and foreshore length changes.

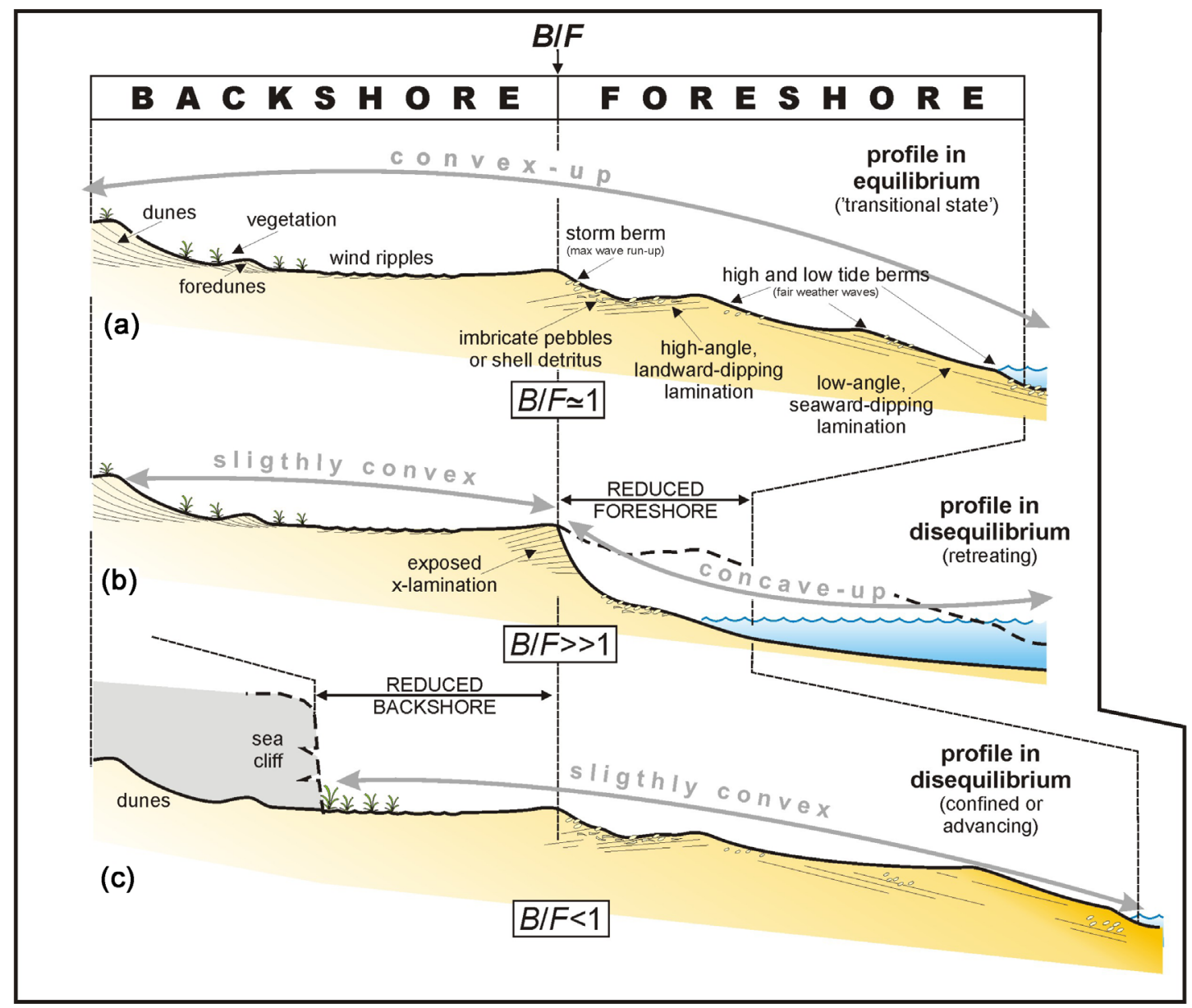

Figure 7. Beach profiles showing the three main $B / F$ end-member conditions. (a) Backshore and foreshore have equal length when a beach approximates to its equilibrium profile during the "transitional state" occurring between the winter and the summer, when it assumes an overall convex-up shape; (b) Foreshore is markedly less extended compared to backshore when the beach is retreating; the beach profile has a typically compound (convex-to-concave) shape; (c) The backshore has a reduced length when: (1) the beach is advancing, with a foreshore that rapidly moves seawards; or (2) the beach is confined landward by the presence of a sea cliff. The schemes also indicate the most common sedimentological and morphological markers that help to identify the limits bounding sub-environments on a subaerial beach. 
The retreating or advancing ratio can thus be quantitatively assessed on the base of the $B / F$ value measured in a beach cross-shore profile and acquired during the time span when a given beach is reaching its own equilibrium (transitional state). This method has been applied and verified on the 36 beach types chosen along the Tyrrhenian and Ionian coasts of Basilicata. For synthesis reasons, only seven of these beaches are illustrated and discussed in the present work, whereas data deriving from the other examples are reported in Table 1.

\section{The Tyrrhenian and Ionian Coasts of Basilicata}

Basilicata lies in the microtidal central Mediterranean (Figure 8), where coasts are generally wave dominated and subject to wide fetches deriving from two or three wind quadrants. Owing to their geographic location in southern Italy, the Basilicata coasts face the Tyrrhenian Sea to the West and the Ionian Sea to the East (Figure 8). These two coastlines exhibit very different morphological and sedimentological features.

The NW-SE-trending Tyrrhenian coast of Basilicata is $\sim 20 \mathrm{~km}$ long (Figure 8) and has a complex coastal morphology, characterised by small promontories and embayments where pocket, gravel beaches occur [51].

The NE-SW-trending Ionian coast of Basilicata is $\sim 40 \mathrm{~km}$ long (Figure 8) and is characterised by sand, subordinately gravel, beaches fed by five deltaic systems that, from SW to NE, are the Sinni, Cavone, Agri, Basento and the Bradano river deltas [52] [53].

The beach examples documented in this paper were acquired in coastal zones where the ubiquitous presence of the human activity was less invasive in the last decades, allowing the preservation of the main original features of the beaches considered. Among the 36 sites measured (see Table 1), 7 beaches were then selected as more representative: 3 along the Tyrrhenian coast and 4 along the Ionian coast (Figure 8). These examples belong to microtidal, wave-dominated oceanographic settings where the wave action, locally combined with alongshore currents, acts as main factor in controlling the coastal dynamics and sediment distribution [54].

\section{Results}

Beach types of western Basilicata (Figure 9(a)) generally range in length from 20 to $40 \mathrm{~m}$ and are characterised by steeper gradients if compared to the eastern coastline (Figure 9(b)), where beaches exhibit gently-sloping inshore profiles over $100 \mathrm{~m}$ long. Backshores and foreshores of these different examples thus reveal highly varying dimensions and features (Table 1). Profile measurements were taken during April-May 2009, 2010 and 2011. During these time spans it is late Spring in such North Temperate Zone localities and all the beach systems are expected to naturally re-establish their primary morpho-sedimentological features after the winter season; for this reason, the acquired measurements are considered as representative of a "beach status" very close to their equilibrium profile. The technique adopted for profile measurement consisted in the use of an electronic theodolite interfaced with a global positioning system (GPS). Topographic data were constantly associated with the observation of the main sedimentological features along the profile.

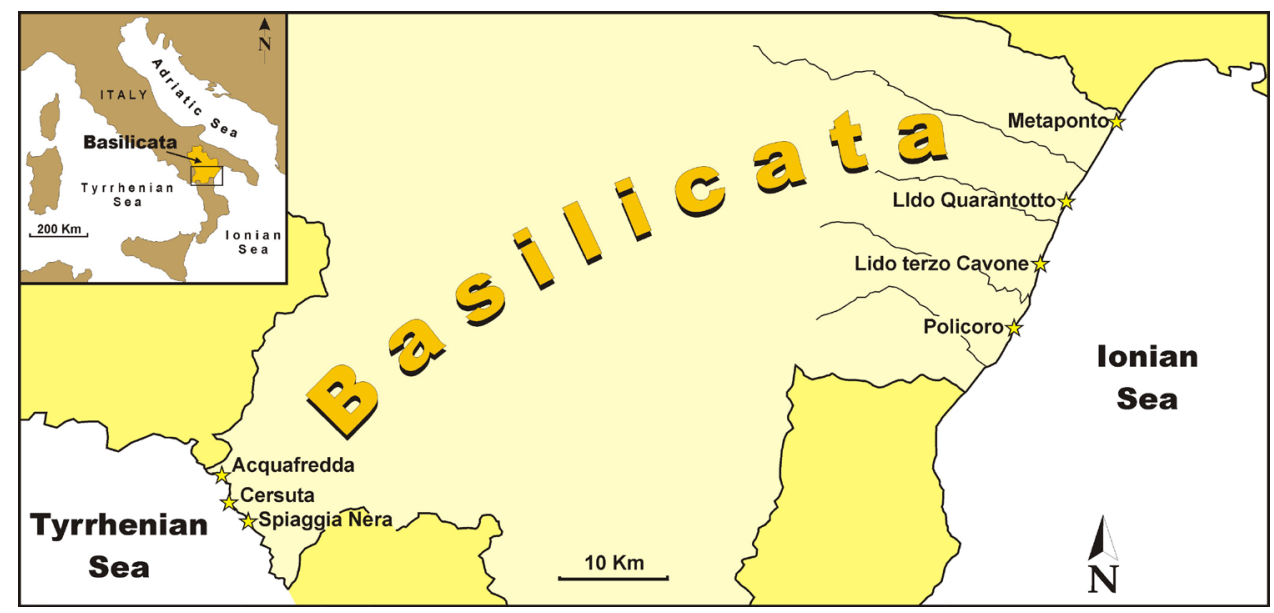

Figure 8. Regional location of Basilicata in the southern Italy with the indication of the studied beaches along the Tyrrhenian (west) and the Ionian (east) coastlines. 
Table 1. Dataset of the studied beach systems along the Tyrrhenian and Ionian Basilicata coasts (all linear values in meters; rectangles enclose the beaches detailed in this study).

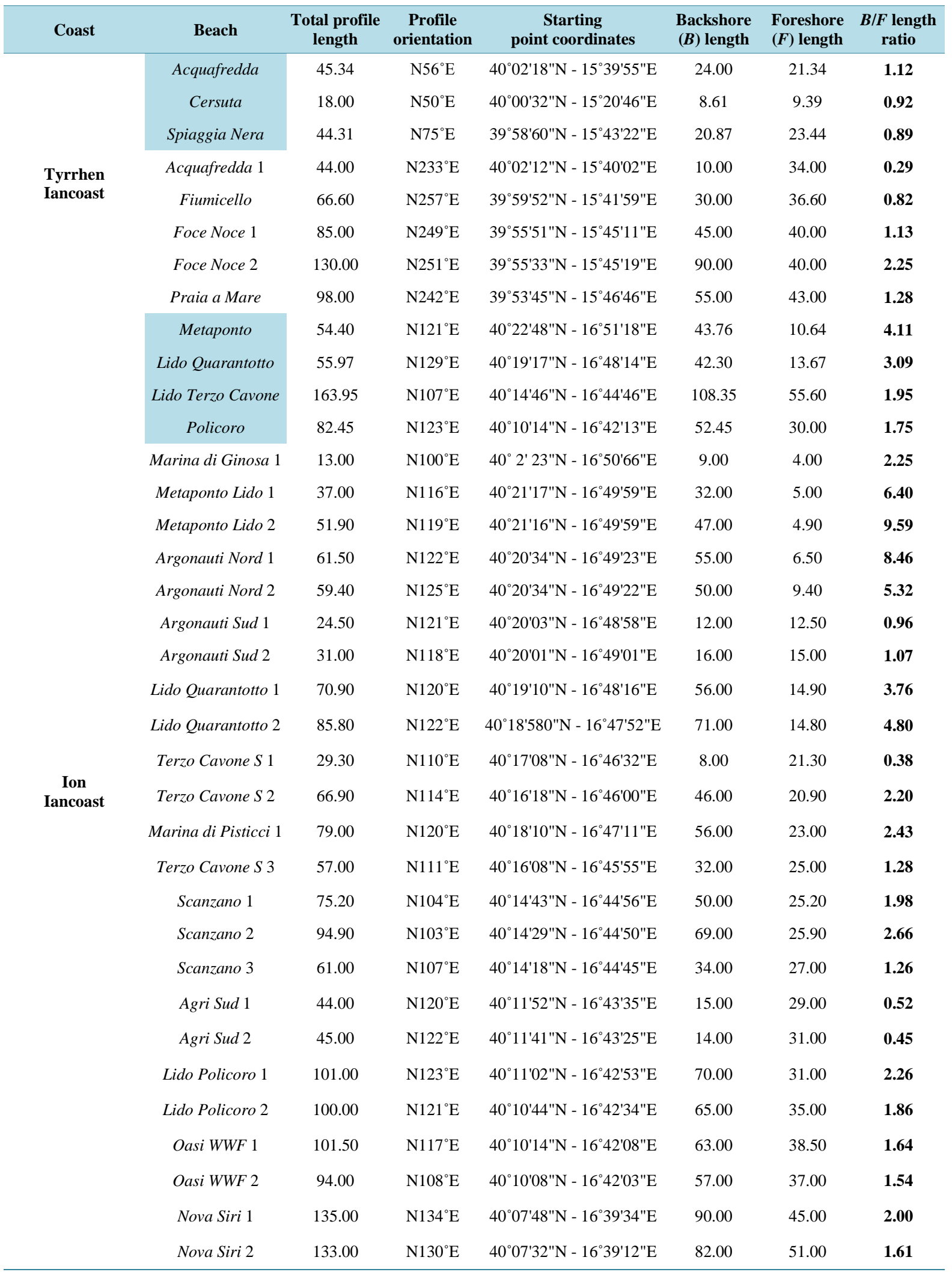



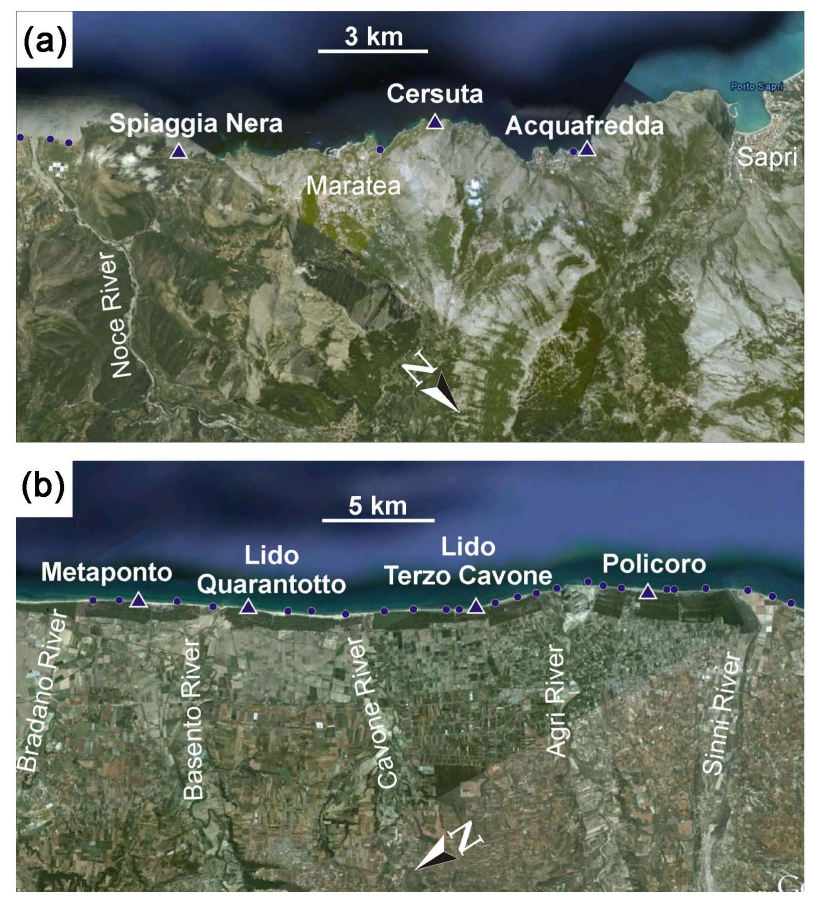

\begin{abstract}
Figure 9. Satellite photographs of the western and eastern coasts of Basilicata (triangles indicate the beaches reported in this study; circles are other studied systems whose features are reported in Table 1). (a) Along the Tyrrhenian coast the three studied beaches are confined systems, sheltered along complex, rocky coastlines; (b) Along the Ionian coast of Basilicata, the four studied beaches lie along a straighttrending sandy shoreline intersected by five river deltas.
\end{abstract}

\title{
5.1. The Tyrrhenian Beach Examples
}

The three beaches selected along the Tyrrhenian coast of Basilicata represent sites where the low anthropogenic impact has partially preserved the primary morpho-sedimentological features of the beach systems. These "pocket beaches" (Acquafredda, Cersuta and Spiaggia Nera in Figure 9(a)) are encased between promontories along a rocky coast. Thus, rather than riverine inputs or littoral drift, these systems are supplied by sediment debris deriving from sporadic sea cliff collapses.

\subsubsection{The Acquafredda Beach}

The Acquafredda beach is a $250 \mathrm{~m}$ long, pocket beach, with a NW-SE-trending shoreline enclosed between promontories (Figure 10(a)). Landwards, Quaternary alluvial deposits of a marine terrace (Figure 10(b)) confine the beach. The $\sim 12^{\circ}-15^{\circ}$ gently-sloping foreshore and the nearly horizontal backshore profiles form a convex-up geometry (Figure 10(b)). Sediment grain-size ranges from granule to pebble, with a marked bimodality observable near the swash zone and in the three orders of small berms. The measured cross-shore profile is $45.34 \mathrm{~m}$ long (profile $\mathrm{Aq}$ in Figure 11(a)). Thus, the $21.34 \mathrm{~m}$ long foreshore (including a $2.80 \mathrm{~m}$ long intertidal zone) passes to a $24 \mathrm{~m}$ long backshore (Table 1 ). The $B / F$ limit corresponds to a change in the profile gradient and to a grain size "break" (Figure 11(a)), where a shoreline-parallel pebble alignment marks the passage to the finer sediments of the backshore. The dune field consists of small wind ripples covered by roadstead vegetation. The $B / F$ length ratio is $1.12(\geq 1)$.

\subsubsection{The Cersuta Beach}

In plan view, the Cersuta beach is a triangular-shaped, pocket beach with a NW-SE-trending 119 m long shoreline (Figure 10(c)). The Cersuta system has an inshore profile ranging in length from a maximum of $\sim 20 \mathrm{~m}$, in proximity of the central sector, to a minimum of $\sim 6 \mathrm{~m}$ near the lateral margins of the beach. The beach profile shows a slightly convex-up shape without any significant angular change (the average dip angle is $18^{\circ}$ ). Sediments are generally coarse grained, ranging from granules to coarse pebbles (Figure 10(d)). The cross-shore 

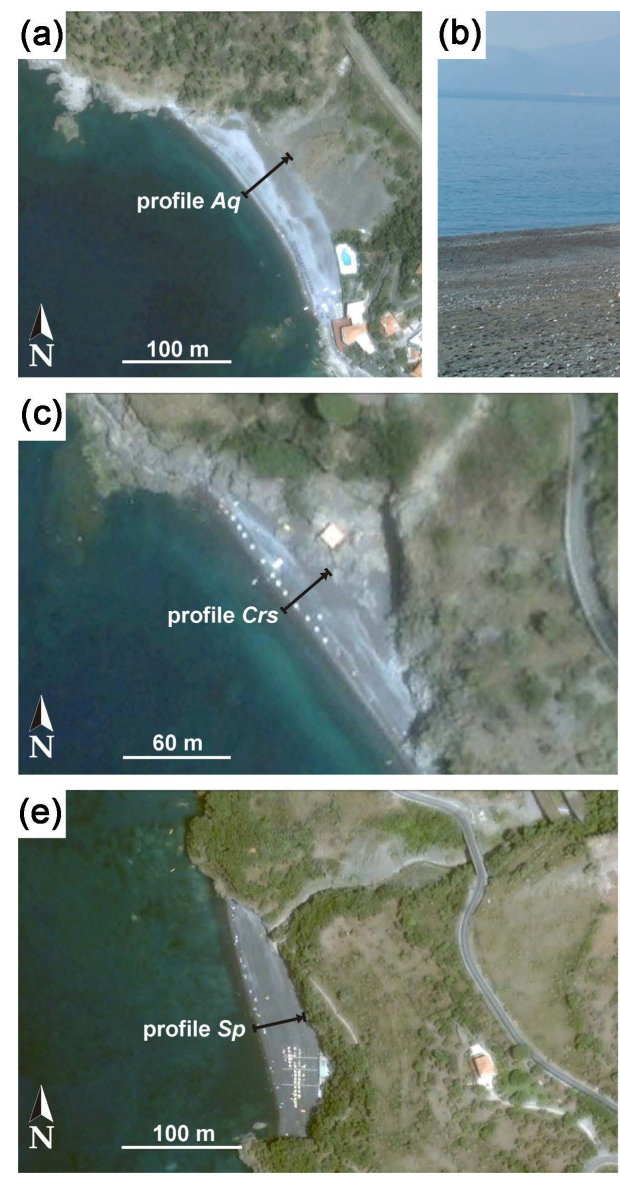

Figure 10. Tyrrhenian beach systems examined in the present study. The Acquafredda ((a) and (b)), Cersuta ((c) and (d)) and Spiaggia Nera ((e) and (f)) beaches (see Table 1 for measurement details).

profile of the subaerial beach (profile Cs in Figure 11(b)) has a total length of $18 \mathrm{~m}$ (the intertidal zone is $\sim 2 \mathrm{~m}$ long), with a $8.61 \mathrm{~m}$ long backshore and a $9.39 \mathrm{~m}$ long foreshore. Also for this example, the $B / F$ limit is marked by a change of the sediment grain size, where clusters of disc-shaped, coarse pebbles indicate the maximum wave run-up during high-energy storms. The $B / F$ length ratio is $0.92(\leq 1)$.

\subsubsection{The Spiaggia Nera Beach}

The NNW-SSE-trending, 202 m long Spiaggia Nera system is another pocket beach where the primary morphosedimentary features are still preserved (Figure 10(e)). The beach shows a slightly convex-up, gently-inclined seaward profile which extends inland from $13 \mathrm{~m}$ to $51 \mathrm{~m}$. Sediments consists of granules to very coarse pebbles, very well sorted along the beach, except for the presence of three main orders of berms, where a marked grain size bimodality occurs (Figure 10(f)). The measured subaerial profile (profile $S P$ in Figure 11(c)) is $44.31 \mathrm{~m}$ long (intertidal zone $=3.58 \mathrm{~m}$ ), and consists of a $20.87 \mathrm{~m}$ long backshore and a $23.44 \mathrm{~m}$ long foreshore. The $B / F$ limit coincides with the last (fifth) berm order and the $B / F$ length ratio is $0.89(<1)$.

\subsection{The Ionian Beach Examples}

Along the Ionian coast of Basilicata, the four beaches reported in this paper (Figure 9(b)) commonly show gently-sloping seaward cross-shore profiles, with a length ranging from less than $10 \mathrm{~m}$ to over $100 \mathrm{~m}$ [55]. Sediments crossing along these beaches are supplied from five rivers debouching along the Ionian coast of Basilicata. A N-directed littoral drift constantly transports $\sim 300 \times 10^{6} \mathrm{~m}^{3}$ of sand/gravel sediment each year [56] [57]. Presently, this shoreline is characterised by a highly varying receding state, amounting to -50 to $-100 \mathrm{~m}$ of retreatment calculated in the 1949-2006 time span [58]. However, some of these beaches exhibited a wide inshore profile during the time of measurements. 

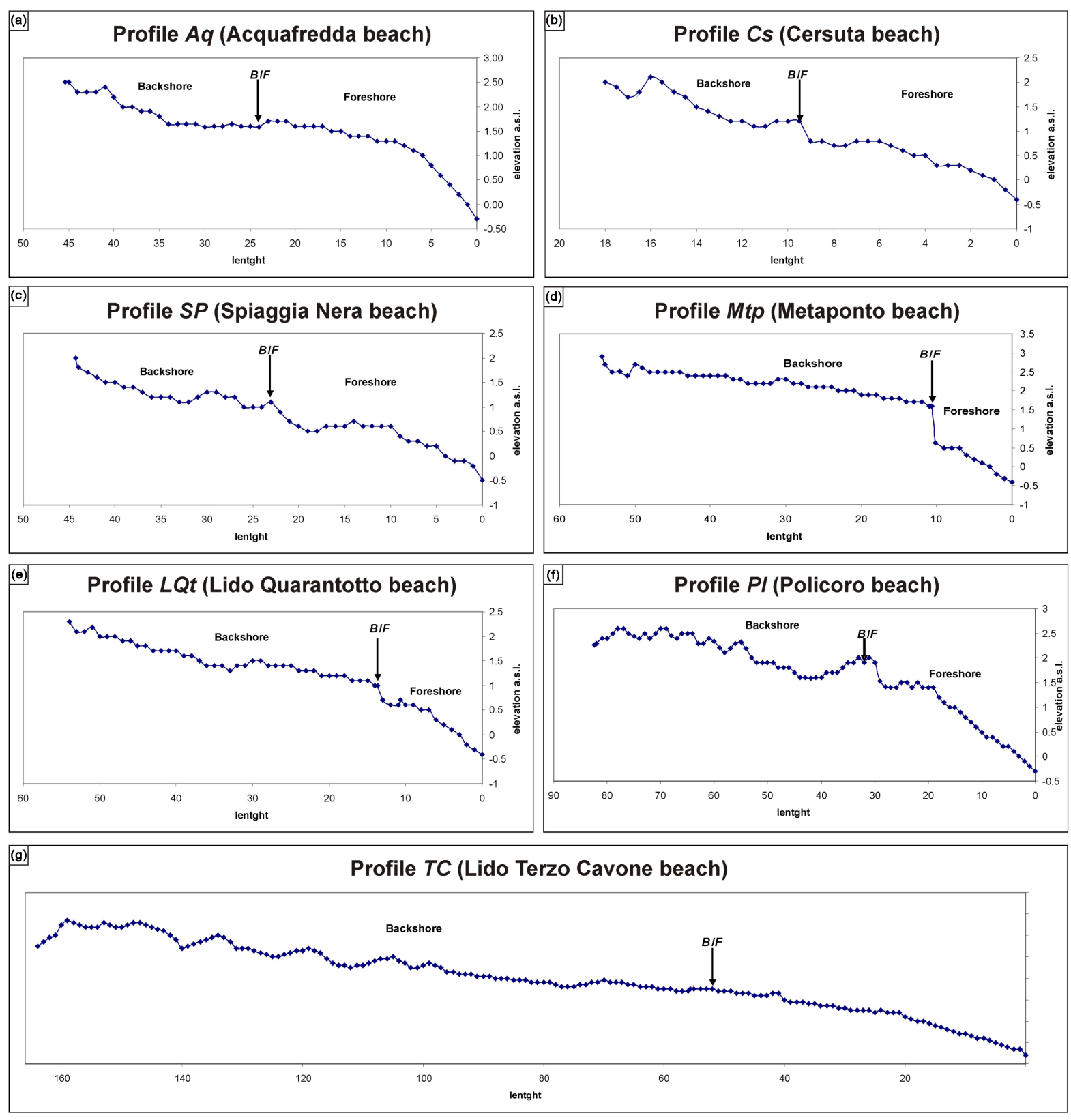

Figure 11. Cross-shore profiles acquired on the subaerial beach of the studied systems (see Table 1 for measurement details). The B/F boundaries are also indicated. Profile acquisitions were taken by using an infrared theodolite interfaced with a GPS satellite system.

\subsubsection{The Metaponto Beach}

The SW-NE-trending Metaponto beach (Figure 9(b)) is a low-gradient, sand beach (Figure 12(a)), characterised by an overall concave-up profile marked by an evident berm incised on to the underlying dune field (Figure 12(b)). This shoreline is strongly receding, although a series of sand nourishments were recently executed from the local government. The beach has a $54.40 \mathrm{~m}$ long cross-shore profile (profile Mtp in Figure 11(d)) which includes a $43.76 \mathrm{~m}$ long backshore and a $10.64 \mathrm{~m}$ long foreshore. The $B / F$ limit corresponds with the base of the main storm berm and a modal pick of grain size. The $B / F$ length ratio is $4.11(\sim 4)$.

\subsubsection{The Lido Quarantotto Beach}

The Lido Quarantotto Beach is located $~ 10 \mathrm{~km}$ southwards the previous example (Figure 12(c)) and consists of 

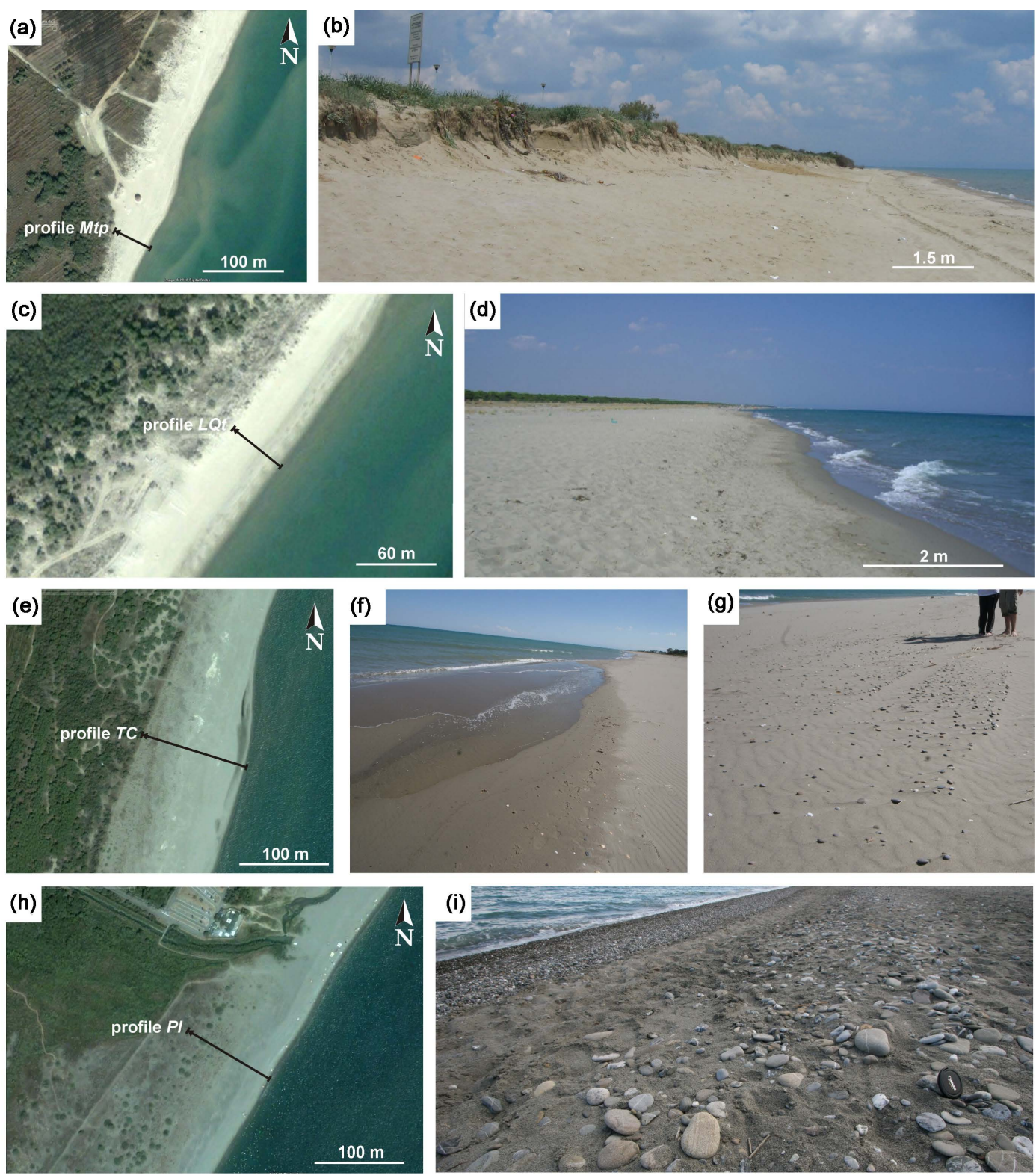

Figure 12. Ionian beaches examined in the present study. The Metaponto ((a) and (b)), Lido Quarantotto ((c) and (d)), Lido Terzo Cavone ((e), (f) and (g)) and the Policoro ((h) and (i)) beaches (see Table 1 for measurement details). Note: In (b) the marked concave-up profile, in (f) the low tide terrace and in (g) the grain size bimodality indicating the $B / F$ boundary on a sand beach. The example in (i) represents the only mixed, sand-gravel beach analysed in this study.

a gently-inclined, sand beach with a 40 - $50 \mathrm{~m}$ of cross-shore profile length (Figure 12(d)). The measured profile (LQt in Figure 11(e)) extends for $55.97 \mathrm{~m}$, with a $42.30 \mathrm{~m}$ long backshore and a $13.67 \mathrm{~m}$ long foreshore (including a $3.22 \mathrm{~m}$ long intertidal zone). The $\mathrm{B} / \mathrm{F}$ limit is detectable on the base of a change in the profile shape from slightly concave-up along the backshore, to markedly convex-up along the foreshore (Figure 11(e)) associated to residual deposits discharged after the storm wave run-up. The $B / F$ ratio is 3.09 ( 3).

\subsubsection{The Lido Terzo Cavone Beach}

$10 \mathrm{~km}$ southwards the previous site, the Lido Terzo Cavone beach occurs (Figure 12(e)). It represents the bestpreserved system of the Ionian coast of Basilicata. This beach lies down current respect to the Agri River mouth (which is located $1.5 \mathrm{~km}$ southwards, Figure 9(b)) and, for this reason, it primarily benefits of this river supply. 
The measured profile (Figure 12(f)) is $163.95 \mathrm{~m}$ long (TC in Figure 11(g)). Its backshore, characterised by sand dunes up to $2 \mathrm{~m}$ high, is $108.35 \mathrm{~m}$ long and is confined landward by a river plain including small swamps, which is seasonally inundated and densely vegetated. Sediments in the backshore are medium to fine sand. The foreshore is $55.60 \mathrm{~m}$ long and consists of coarse to very coarse sand with subordinate pebbles. It includes a series of $0.2-0.4 \mathrm{~m}$ high berms and a $\sim 10 \mathrm{~m}$ long intertidal zone. This latter forms a low-tide terrace, which is exposed during six hours per day (Figure 12(f)). The B/F is $1.95(\sim 2)$ and coincides with a small scarp associated to vegetal remains and scattered pebbles (Figure 12(g)).

\subsubsection{The Policoro Beach}

The Policoro beach is located $\sim 3$ km N the Sinni River mouth (Figure 9(b) and Figure 10(h)). This latter discharges abundant sands and gravels that supply parallel-to-shoreline subaqueous bars [57]-[61]. During highenergy waves, these bars undergo momentary erosion [59] [60]; sediment eroded from the bars is thus discharged on to the adjacent foreshore under the form of gravel cusps. Consequently, the Policoro beach results a mixed (sand/gravel) system (Figure 12(i)): Medium-fine sands dominate in the backshore, generating aeolian dunes up to $2 \mathrm{~m}$ high, whereas gravels and subordinate coarse sands abound in the foreshore. Here, pebbles form several orders of belts ("facies belt" of [61]-[63]) shaped into berms, with crests coarser than troughs. The measured profile of the Policoro beach ( $\mathrm{Pl}$ in Figure 12(f)) is $82.45 \mathrm{~m}$ long and includes a $52.45 \mathrm{~m}$ long backshore and a $30.00 \mathrm{~m}$ long foreshore. The $B / F$ is 1.75 .

\section{Discussion}

\subsection{B/F Ratio Classes}

The subdivision between backshore and foreshore detected in the studied subaerial beaches based on their genetic significance and bi-dimensional length, allows assessing quantitatively the state of equilibrium or disequilibrium at the time of the profile measurement. Advancing, receding and stable beaches are thus identifiable into seven classes of beach states obtained by their respective values, or value intervals, of the $B / F$ length ratio (Table 2). Accordingly, $B / F<0.5$ indicates "strongly advancing" beaches that may correspond to the "Class I"; $B / F$ comprised between 0.5 and 0.8 indicates "moderately advancing" beaches ("Class II"), and $B / F$ comprised between 0.8 and 1 "slightly advancing" beaches ("Class III"). "Stable" beaches with $B / F=1$ correspond to the "Class IV". Analogously, values of $B / F$ comprised between 1 and 2 indicate "slightly receding" beaches of the "Class V", $2<B / F<3$ corresponds to "moderately receding” beaches of the "Class VI" and, finally, $B / F>3$ designates "strongly receding” beaches of the "Class VII" (Table 2).

\subsection{Retreating vs. Advancing Beaches of the Basilicata Coastlines}

As documented by a number of studies (e.g., [64] [65] among others), over the $60 \%$ of the Italian coastlines presently undergo a state of retreatment, because the concurrent influences of anthropogenic and natural forcing factors [66]. The human impact along the southern Italy coasts has increased greatly in the last decades, because the strong touristic pressure and the effects of many hydraulic regulation works carried out in the drainage

Table 2. Subdivision into seven classes of advancing, receding and stable beaches on the base of their respective value intervals of $B / F$ length ratio.

\begin{tabular}{|c|c|c|c|}
\hline \multicolumn{2}{|c|}{ Class } & Beach State & $B / F$ Length Ratio \\
\hline \multirow{3}{*}{ Advancing } & I & Strongly Advancing & $<0.5$ \\
\hline & II & Moderately Advancing & $0.5-0.8$ \\
\hline & III & Slightly Advancing & $0.8-1$ \\
\hline \multirow{4}{*}{ Receding } & IV & $\begin{array}{c}\text { Stable } \\
\text { (Neither Advancing Nor Receding) }\end{array}$ & 1 \\
\hline & $\mathrm{V}$ & Slightly Receding & $1-2$ \\
\hline & VI & Moderately Receding & $2-3$ \\
\hline & VII & Strongly Receding & $>3$ \\
\hline
\end{tabular}


basins behind the coasts (e.g., [67]). Concurrently, the very rapid sea-level rise documented in the last decades in the Mediterranean and related to the effect of the global warming, is seriously contributing to accelerate the state of erosion along the Italian shorelines [66].

The beach examples analysed in the present study pertain to two very different coastlines, including sand, gravel and mixed beaches. All these beaches lie in states of retreatment, advancement or stability depending on highly varying local conditions of sediment supply, morphological confinement and exposure to dominant winds and waves.

The Tyrrhenian beaches are confined or semi-confined systems (Figure 11). As documented in many studies (e.g., [68]), pocket beaches are less frequently subject to shoreline retreat if compared to laterally-unconfined systems. Since the main sediment supply for a beach derives from the littoral drift, pocket beaches are excluded from this type of clastic supply, because comprised between rocky promontories that are natural barriers for alongshore sediment distribution. Pocket beaches are directly nourished from inland processes, such as seawall collapses or alluvial fan reactivations that can contribute greatly in supplying a beach independently from highfrequency, climate-driven sea level changes (e.g., [28]). Therefore, the correspondent examples studied in this work have shown beaches that nearly approximate to the equilibrium. This state is confirmed by convex-up profile shapes and $B / F$ length ratios $\approx 1$, which indicate that backshore and foreshore have nearly-equivalent lengths (e.g., Acquafreddabeach, Figure 11(a)). Profiles with $B / F$ length ratio $<1$ indicate advancing beaches or backconfined beaches, whose backshore developed in restricted space, if compared to the foreshore (e.g., Cersuta and Spiaggia Nera beaches, Figure 9(b) and Figure 9(c)). Beaches observed along the Tyrrhenian coastline are thus included in Classes III and IV of Table 2.

The Ionian examples allow verifying the $B / F$ ratio in different settings. Previous studies have documented as the retreating tendency of the Ionian beaches varies greatly, from strongly-receding beaches in the north-eastern sector (Metaponto) to slightly-receding beaches in the south-western sector (Terzo Cavone) [69] [70]. This progressive reduction in the extension of the shoreline was attributed to the northward narrowing of the continental shelf width and the consequent vicinity of the canyon heads [71]. The $B / F$ ratio increases from the southern to the northern beaches, ranging from 1.75 to 4.11 . The lower values, somewhat $>1$, express quasi-equilibrium states, and this condition is also supported by compound (concave- to convex-up) 2D profiles acquired in the Policoro and Terzo Cavone beaches (Figure 9(f) and Figure 9(g)). These systems are in fact the best-preserved beaches observed along the Ionian coast of Basilicata where, although the shoreline is generally affected by a long-term retreat, some beaches show shorter-term local advancement, due to their position adjacent to river mouths. $B / F$ ratios $>>1$ indicates an extremely reduced foreshore and thus strong erosion for the Metaponto and Lido Quarantotto beaches (Figure 9(d) and Figure 9(e)), whose profiles maintain concave-up shapes also during the transitional state separating winter from summer. The beaches documented along this coastline are therefore included in Classes V, VI and VII of the subdivision proposed in Table 2.

\subsection{The Importance of the Subaerial Beach in Shoreline Measurements}

The morphological profile observed in the studied beaches from the Tyrrhenian and Ionian coastlines of Basilicata results from a series of dynamic processes that shape the littoral, leaving the signature of their energy, duration and direction [72]. The beach morphology is thus regulated by processes of various magnitudes and frequencies. Attempts have been made to understand these shapes in terms of "morphodynamic equilibrium" and "transitional states" [1] [2]. Modern shorefaces tend towards an equilibrium cross-shore profile that forms in response to fair-weather wave processes of low magnitude and high frequency [9]-[73]. However, most shoreface-shelf deposits record storm-wave processes of high magnitude and low frequency, which are preferentially preserved in the stratigraphic record [74]-[78]. Thus, the portion of the shoreface-shelf profile above fairweather wave base maintains an equilibrium profile, whereas that below fair-weather wave base is widely interpreted to respond over longer timescales to episodic storm waves (e.g., [79]-[81]). Therefore, the concept of equilibrium profile is most applicable to the upper parts of the shoreface-shelf profile (above fair-weather wave base) where the timescale of intrinsic, dynamic response is fast relative to changes in extrinsic controls such as sea level, sediment supply and wave climate [80].

The morpho-bathymetric profile of a shoreface changes continuously in time, because primarily subjected to the wave action during either fair-weather and storm episodes [14]. Also sediments change their distribution over bars, troughs and runnels that occur along this profile [16]. However, as systematic measurements repeated along the shoreface demonstrate as these variations depend upon a number of processes, some of which do not 
influence directly the equilibrium of the subaerial beach [80]. For instance, bathymetric measurements acquired during the high-energy season across the Ionian shelf of Basilicata demonstrate as if the subaerial beach lies momentary under a state of recession, the shoreface is on the contrary highly constructive, because it receives large amount of sediments deriving from the transport of vigorous longshore currents that re-distribute the deposits previously eroded from the foreshore during storms [54]-[58]. Moreover, it is widely documented as, after high-energy events, the part of the beach that suffers of the maximum sediment deficit is its subaerial sector rather than its subaqueous counterpart, since the post-storm process of beach restoration accumulates more rapidly in the shoreface due to the re-distribution action of shoaling waves and seaward-directed rip currents (e.g., [28]-[82]). For these reasons, the subaerial beach is the only physical element capable to record real states of deficit or surplus of sediments during a seasonal cycle of shoreline advancement or recession.

\subsection{Temporal Scale of the Observations}

Temporal changes in external controls, including (i) amount of sediment discharged from the rivers, (ii) wave climate and (iii) persistence of along shore currents, alter the geometry of the equilibrium profile (e.g., [77] [78]). Such variability is likely to occur over seasonal to yearly or longer timescales, for example in response to minor, climatically driven changes in the relative sea level.

The subaerial sector of a beach can be consistently considered as that part of a beach that is primarily subject to the effect of a short-term modification of the state of equilibrium. This modification occurs as: 1) a morphological change of the profile shape; 2 ) a redistribution of sediments along the profile; and 3) a variation of the length of its components (backshore and foreshore). Therefore, the seasonal-scale measurements of a beach profile allow identifying short-term trends in a changing coastline.

However, it is well known that a one-year-long beach evolution occurs through a series of "stages" (expressed by different topographic profiles) which endpoints are represented by the winter and summer profiles (see again Figure 2) [83]-[87]. These stages result from cut and fill alternations over seasons, producing beach profiles that show changes in form, being higher and wider after phases of accretion and lower and flatter (with a backing rise or cliff) after phases of erosion [7]. Systematic surveys across the beach can determine the cross-sectional area between the accreted and eroded profiles ("sweep zone"). For example, measurements on the Ninety Mile Beach, in SE Australia [7], have shown that the seasonal sweep zone has a mean cross-sectional area that indicates equivalent mass loss/replacements between winter and summer. This balance implies that variations are cyclically restored on such a beach profile by natural processes over seasonal periods of time and involving quasiequivalent sediment masses.

Thus, a beach profile which is measured in the middle of this continuum that cyclically (even not regularly) moves between two end-members, can be theoretically considered as a close approximation of the equilibrium profile. A subaerial profile acquisition during this transitional state represents an "instantaneous picture" on the state of preservation of the physical components of a beach which is balancing on a dynamic equilibrium.

This trend is a short-term variations of a longer-term tendency calculated over tens of years (e.g., temporary beach accretion could result from a high-frequency (seasonal) state of shoreline advancement over a period of general retreating).

\subsection{Short- vs. Long-Term Beach States}

As shown in Figure 13(a), backshore and foreshore length values combined in a bi-dimensional plot identify two main fields for advancing vs. retreating systems. Data points are scattered across a linear tendency line (solid red line in Figure 13(a)), whose goodness-of-fit coefficient indicates a sparse distribution $\left(R_{T}^{2}=0.14\right)$.

This plot can also be used to estimate long-term retreatment/advancement patterns for beaches with known $B / F$ ratio. The example in (b) shows a $y$-axis-directed deviation from the trend line that indicates as all the measurements, whose data points are dispersed in the top-left corner of the diagram, belong to a long-term retreating shoreline. Such a tendency implies, for instance, that beaches showing $B / F<1$ undergo momentary states of accretion during a longer-term recession $\left(\alpha_{\mathrm{T}}>\alpha_{\mathrm{C}}\right)$ (see Figure 14). On the contrary, the plot in (c) shows $x$-axisdirected displacement from the trend line $\left(\alpha_{\mathrm{T}}<\alpha_{\mathrm{C}}\right)$, indicating the short-term beach adjustments during a generalised phase of shoreline advancement $\left(\alpha_{\mathrm{T}}\right.$ and $\alpha_{\mathrm{C}}=$ angular coefficients of the Trend and Correlation lines). 

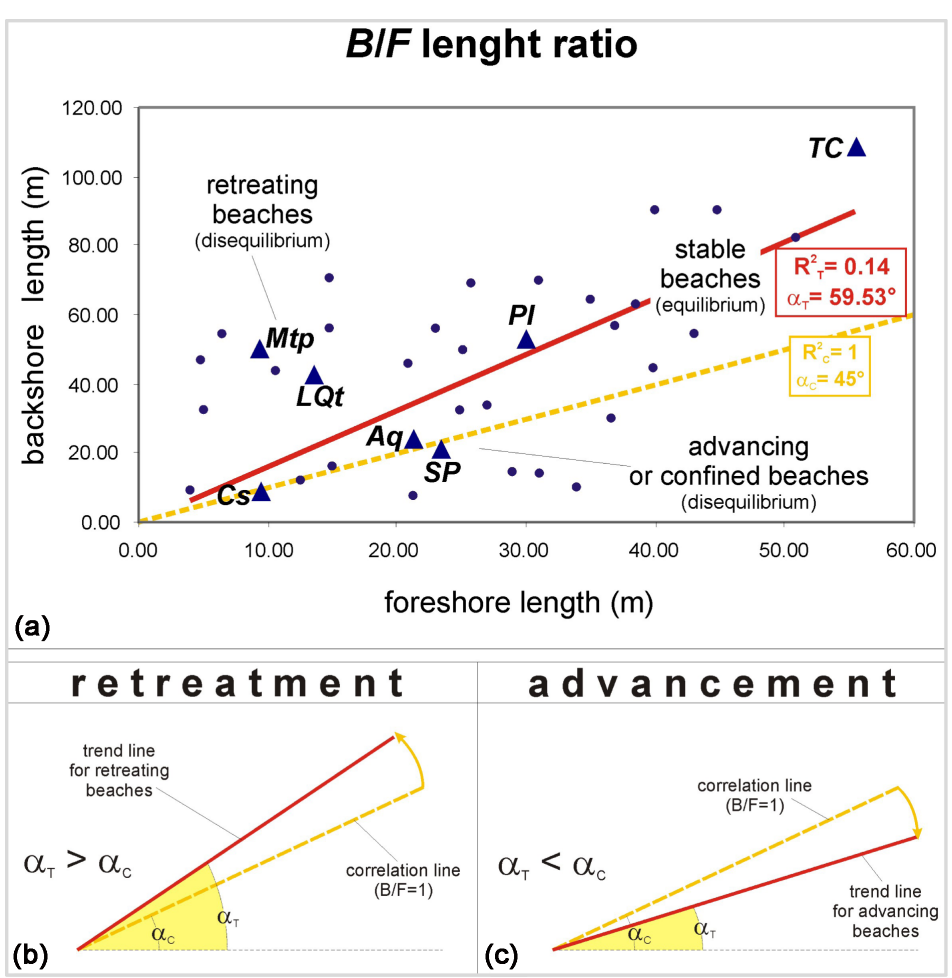

Figure 13. (a) $B / F$ length ratio plotted for 36 beach profiles (triangles indicate the examples documented in this study). Three main fields of existence indicate as many beach conditions: retreating beaches are characterised by backshores larger than foreshores; advancing beaches have longer foreshores; beaches that approximate to their equilibrium profile lie along the red trend line $\left(\mathrm{R}^{2}\right.$ value is the trend line's goodness-of-fit coefficient; $\alpha$ is the trend line's angular coefficient; line intercepts the 0 in the plot). The lower dashed line (in yellow) represents the correlation line including backshores and foreshores with equal lengths $\left(\mathrm{R}^{2}=1\right.$ because all data points are expected to be aligned along this line) (letter symbols: Mtp = Metaponto; LQt = Lido Quarantotto; $\mathrm{Cs}=$ Cersuta; $\mathrm{Aq}=$ Acquafredda; $\mathrm{SP}$ = Spiaggia Nera; $\mathrm{Pl}=$ Policoro; TC = Lido Terzo Cavone).

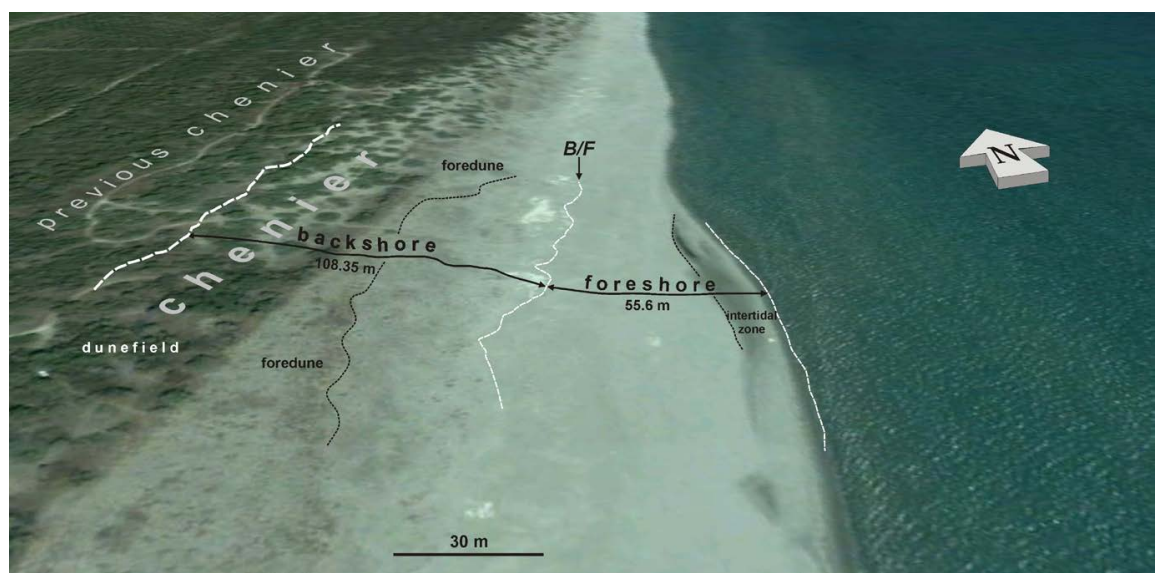

Figure 14. Panoramic view of the cross-shore profile measured at the Lido Terzo Cavone beach (see Figure 9(b) for location). At the time of the profile acquisition, this beach exhibited features, which were typical of an advancing shoreline, including a wide and convex-up inshore profile and the presence of a low-tide terrace. However, a backshore with an extension almost twice than the foreshore $(B / F=1.95)$, suggests larger dimensions for this beach in the past. This $B / F$ value thus expresses a short-term (seasonal) advancement during a longer-term phase of shoreline retreatment (Class $\mathrm{V}$ of the subdivision proposed in Table 2). The internal limit separating the present-day beach from previous cheniers was obtained from aerial image analysis (picture from Google Earth $^{\circledR}$ ). 
Retreating beaches are positioned around the top-left corner of the diagram, where data indicate long backshores associated with small foreshores. Beaches with foreshore longer than backshore are placed in the bottom of the plot. These two areas point out: 1) shoreline erosion and consequent retreating beaches and 2) advancing beaches or cliff-confined beaches, respectively (Figure 13(a)). These conditions suggest states of morphodynamic disequilibrium due to the natural attempt of the beach to reach a stability profile which, according to the model proposed in this work, corresponds with equivalent backshore and foreshore lengths. Accordingly, systems in equilibrium are virtually stationary (neither retreating nor advancing) and are distributed along the tendency line (Figure 13(a)).

In the present example, the trend line is displaced with respect the correlation line traced between equivalent $x$, $y$ values (dotted line in Figure 13(a)). The plot of Figure 13(a) shows that the trend line obtained from the scattered points has a clear $y$-axis-directed deviation $(\sim 32 \%)$ respect to the correlation line. The possible significance of this deviation can be used to estimate long-term pattern of shoreline changes, as in the example reported in Figure 13(b) and Figure 13(c). These plots summarize two hypothetical conditions where the trend line shows $y$-axis- and $x$-axis-directed displacements, respectively. In the first case (Figure 13(b)) all the B/F linear ratio points measured for $n$ beaches are dispersed in the top-left corner of the diagram. Such a tendency implies, for instance, that beaches showing $B / F<1$ undergo momentary states of accretion during a longer-term recession (see example in Figure 14). Thus, the dip angle of the trend line of the measured beaches $\left(\alpha_{\mathrm{T}}\right)$ is greater than the dip angle of the correlation line $\left(\alpha_{\mathrm{C}}\right)$. Conversely, the plot in Figure 13(c) shows the alternative possibility where $B / F$ measurements indicate shorelines under a long-term tendency of advancement $\left(\alpha_{\mathrm{T}}<\alpha_{\mathrm{C}}\right)$. Concerning the dataset obtained in the present study, the shift of the trend line in the field of retreating beaches may thus confirm the general receding tendency of the shorelines from where many of the examined examples derive (see example of Figure 14).

\section{Conclusions}

In this paper the bi-dimensional extension of the subaerial part of microtidal, wave-dominated beaches are considered as proxy in the short-term evaluation of their state of morphodynamic equilibrium. During the passage from the high-energy to the lower-energy season, a beach crosses a "transitional state", represented by a quasiequilibrium profile whose shape lies between the two endpoints of the winter and summer profiles. This intermediate state reflects more faithfully the mean dynamics of a beach that results in the dimension of its physical components forming the subaerial sector. Thus, backshore and foreshore, if properly detected and bi-dimensionally measured, can be consistently related to the state of beach retreatment or advancement, at the moment of the profile acquirement.

This very quick and low-cost method thus requires only one profile measurement per year, which has to be strategically acquired during the late spring or fall, when a beach is expected to lie in its "transitional state".

The $B / F$ length ratio calculated in 36 sand, gravel and mixed, microtidal, wave-dominated beaches (7 of which were focused in this paper) indicates that foreshore and backshore have equal lengths along stable shorelines. Backshore length exceeding foreshore length was instead detected in retreating beaches. Systems with opposite conditions (foreshore greater than backshore) indicate advancing beaches or confined (pocket) systems. These states, summarised into seven classes, identify numerically ranges of advancing, retreating and stable beach conditions.

\section{Acknowledgements}

Financial support for this research was provided by Ministero dell'Università e della Ricerca Scientifica (ex 60\% Grant 2010-2011 to S. G. Longhitano). An early version of this manuscript benefited of the constructive comments by Dr. William A. Birkemeier and Dr. Robert J. Thompson. The author would like to thank Prof. Giuseppe dell'Olio for the stimulating discussion on the meaning of the $B / F$ plots and the MSc students of the Coastal Dynamics class at the Basilicata University, for their enthusiastic help during beach profile measurements.

\section{References}

[1] Bruun, P. (1954) Coastal Erosion and the Development of Beach Profiles. Beach Erosion Board Technical Memo, No. 44, US Army Engineer Waterways Experiment Station, Vicksburg. 
[2] Dean, R.G. (1977) Equilibrium Beach Profiles: US Atlantic and Gulf Coasts. Ocean Engineering Report, No. 12, University of Delaware, Newark.

[3] Emery, K.O. (1961) A Simple Method of Measuring Beach Profiles. Limnology and Oceanography, 6, 90-93. http://dx.doi.org/10.4319/lo.1961.6.1.0090

[4] Krause, G. (2004) The "Emery-Method” Revisited-Performance of an Inexpensive Method of Measuring Beach Profiles and Modifications. Journal of Coastal Research, 20, 340-346. http://dx.doi.org/10.2112/1551-5036(2004)20[340:TEROAI]2.0.CO;2

[5] Karunarathna, H., Horrillo-Caraballo, J.M., Reeve, D.E. and Spivack, M. (2011) Analysis of Key Parameters in a Diffusion Type Beach Profile Evolution Model. Continental Shelf Research, 31, 98-107. http://dx.doi.org/10.1016/j.csr.2010.11.008

[6] Woodroffe, C.D. (2003) Coasts, Form, Process and Evolution. Cambridge University Press, Cambridge.

[7] Bird, E.C.F. (2008) Coastal Geomorphology: An Introduction. 2nd Edition, John Wiley \& Sons, New York.

[8] Bird, E.C.F. (2003) The World’s Coasts: Online. An Electronic Encyclopedia. Springer, Dordrecht.

[9] Walker, R.G. and Plint, A.G. (1992) Wave- and Storm-Dominated Shallow Marine Systems. In: Walker, R.G. and James, N.P., Eds., Facies Models: Response to Sea Level Change, Geological Association of Canada, Newfoundland, 219238.

[10] Clark, J.R. (1996) Coastal Zone Management Handbook. Lewis Publishers, Boca Raton.

[11] Elliott, T. (1986) Clastic Shorelines. In: Reading, H.G., Ed., Sedimentary Environments and Facies, Blackwell, Oxford, 113-154.

[12] Davis Jr., R.A. (1985) Beach and Nearshore Zone, Coastal Sedimentary 557 Environments. In: Davis Jr., A. and Richard, R.A., Eds., Coastal Sedimentary Environments, Springer-Verlag, New York, 379-443.

[13] Davidson-Arnott, R. (2005) Beach and Nearshore Instrumentation. In: Schwartz, M.L., Ed., Encyclopedia of Coastal Science, Springer, Dordrecht, 130-138.

[14] Davidson-Arnott, R. (2010) Introduction to Coastal Processes and Geomorphology. Cambridge University Press, Cambridge.

[15] Morton, R.A. (1979) Temporal and Spatial Variations in Shoreline Changes and Their Implications, Examples from the Texas Gulf Coast. Journal of Sedimentary Petrology, 49, 1101-1111.

[16] Komar, P.D. (1998) Beach Processes and Sedimentation. 2nd Edition, Prentice-Hall, Englewood-Cliffs.

[17] Hayes, M.O. (1979) Barrier Island Morphology as a Function of Tidal 583 and Wave Regime. In: Latherman, S.P., Ed., Barrier Island - From the Gulf of St. Lawrence to the Gulf of Mexico, Academic Press, New York, 1-71.

[18] Clifton, H.E., Hunter, R.E. and Phillips, R.L. (1971) Depositional Structures and Processes in the Non-Barred, HighEnergy Nearshore. Journal of Sedimentary Petrology, 41, 711-726.

[19] Bourgeois, J. and Leithold, E. (1984) Wave-Worked Conglomerates-Depositional Processes and Criteria for Recognition. In: Koster, E.H. and Steel, R.J., Eds., Sedimentology of Gravels and Conglomerates, Memories Canadian Society Petroleum Geologists, Vol. 10, 331-343.

[20] Dean, R.G. and Darlymple, R.A. (2004) Coastal Processes, with Engineering Applications. Cambridge University Press, Cambridge.

[21] Evans, O.F. (1940) The Low and Ball of the East-Shore of Lake Michigan. Journal of Geology, 48, 467-511. http://dx.doi.org/10.1086/624905

[22] King, C.A.M. and Williams, W.W. (1949) The Formation and Movement of Sand Bars by Wave Action. Geographical Journal, 113, 70-85. http://dx.doi.org/10.2307/1788907

[23] Davis Jr., R.A., Fox, W.T., Hayes, M.O. and Boothroyd, J.C. (1972) Comparison of Ridge and Runnel Systems in Tidal and Non-Tidal Environments. Journal of Sedimentary Petrology, 42, 413-421.

[24] Leatherman, S.P., Whitman, D. and Zhang, K. (2005) Coastal Erosion Hazard Mapping Using LIDAR (Airborne Laser Altimetry Technology). In: Schwartz, M.L., Ed., Encyclopedia of Coastal Science, Kluwer Academic Publishers, Dordrecht, 21-24.

[25] Hanamgond, P.T. and Mitra, D. (2008) Evolution of Malvan Coast, Konkan, West Coast of India—A Case Study Using Remote Sensing Data. Journal of Coastal Research, 24, 672-678. http://dx.doi.org/10.2112/06-0692.1

[26] Darke, I., Davidson-Arnott, R. and Ollerhead, J. (2009) Measurement of Beach Surface Moisture Using Surface Brightness. Journal of Coastal Research, 25, 248-256. http://dx.doi.org/10.2112/07-0905.1

[27] Short, A.D. (1993) Beach and Surf Zone Morphodynamics. Journal of Coastal Research, 15, 25-37.

[28] Short, A.D. (1999) Beach and Shoreface Morphodynamics. John Wiley and Sons, Chichester. 
[29] Cooper, N.J., Leggett, D.J. and Lowe, J.P. (2000) Beach-Profile Measurement, Theory and Analysis: Practical Guidance and Applied Case Studies. Water and Environment Journal, 14, 79-88. http://dx.doi.org/10.1111/j.1747-6593.2000.tb00231.x

[30] Smith, R.K. and Benson, A.P. (2001) Beach Profile Monitoring: How Frequent Is Sufficient? Journal of Coastal Research, 34, 573-579.

[31] Delgado, I. and Lloyd, G. (2004) A Simple Low Cost Method for One Person Beach Profiling. Journal of Coastal Research, 20, 1246-1252. http://dx.doi.org/10.2112/03-0067R.1

[32] King, C.A.M. (1959) Beaches and Coasts. Edward Arnold, London.

[33] Ottmann, F. (1965) Géologie marine et litorale. Masson, Paris.

[34] Ingle, J.C. (1966) The Movement of Beach Sand. Elsevier, Amsterdam.

[35] Shepard, F.P. (1967) Submarine Geology. Harper International Edition, New York.

[36] Shepard, F.P. (1973) Submarine Geology. Harper and Row, New York.

[37] Carobene, L. and Brambati, A. (1975) Metodo per l'analisi morfologica quantitativa delle spiagge. Bollettino Società Geologica Italiana, 94, 479-493.

[38] Howard, J.D. and Reineck, H.E. (1981) Depositional Facies of High-Energy Beach-to-Offshore Sequence: Comparison with Low-Energy Sequence. American Association of Petroleum Geologists Bulletin, 65, 807-830.

[39] US Army Corps of Engineers (1984) Shore Protection Manual. Coastal Engineering Research Center, US Government Printing Office, Washington DC, 3.

[40] US Army Corps of Engineers (1995) Coastal Geology. Coastal Engineering Research Center, US Government Printing Office, Washington DC, 4.

[41] Schwartz, M.L. (2005) Encyclopedia of Coastal Science. Springer, Dordrecht. http://dx.doi.org/10.1007/1-4020-3880-1

[42] Mase, H. (1989) Random Wave Run-Up Height on Gentle Slopes. Journal of Waterway, Port, Coastal, and Ocean Engineering, 115, 649-661. http://dx.doi.org/10.1061/(ASCE)0733-950X(1989)115:5(649)

[43] Nielsen, P. and Hanslow, D.J. (1991) Wave Run-Up Distributions on Natural Beaches. Journal of Coastal Research, 7, 1139-1152.

[44] Sorensen, R.M. (1997) Basic Coastal Engineering. Chapman and Hall, New York.

[45] ARC (2000) Coastal Hazard Strategy and Coastal Erosion Manual. Auckland Regional Council Technical, Auckland, 130.

[46] Bell, R.G. and Gorman, R.M. (2003) Coastal Hazards. Ministry of Civil Defence and Emergency Management, Wellington, Tephra, 20, 21-26.

[47] Pirazzoli, P.A., Stiros, S.C., Arnold, M., Laborel, J. and Laborel-Deguen, F. (1999) Late Holocene Coseismic Vertical Displacements and Tsunami Deposits Near Kynos, Gulf of Euboea, Central Greece. Physics and Chemistry of the Earth, 24, 361-367. http://dx.doi.org/10.1016/S1464-1895(99)00042-3

[48] Mastronuzzi, G. and Sansò, P. (2000) Boulders Transport by Catastrophic Waves along the Ionian Coast of Apulia (Southern Italy). Marine Geology, 170, 93-103. http://dx.doi.org/10.1016/S0025-3227(00)00068-2

[49] Dominey-Howes, D., Cundy, A. and Croudace, I. (2000) High Energy Marine Flood Deposits on Astypalaea Island, Greece: Possible Evidence for the AD 1956 Southern Aegean Tsunami. Marine Geology, 163, 303-315. http://dx.doi.org/10.1016/S0025-3227(99)00100-0

[50] de Lange, W.P. and Moon, V.G. (2005) Estimating Long-Term Cliff Recession Rates from Shore Platform Widths. Engineering Geology, 80, 292-301. http://dx.doi.org/10.1016/j.enggeo.2005.06.004

[51] Carobene, L. and Dai Pra, G. (1991) Middle and Upper Pleistocene Sea Level Highstands along the Tyrrhenian Coast of Basilicata (Southern Italy). Il Quaternario Italian Journal of Quaternary Sciences, 4, 173-202.

[52] Cocco, E., Cravero, E., Di Geronimo, S.I., Mezzadri, G., Parea, G.C., Pescatore, T., Valloni, R. and Vinci, A. (1975) Lineamenti geomorfologici e sedimentologici del litorale alto ionico (Golfo di Taranto). Bollettino della Societa Geologica Italiana, 94, 993-1051.

[53] Parea, G.C., Fontana, D., Valloni, R. and Vinci, A. (1980) Dispersione dei sedimenti ed evoluzione della costa fra Capo Spulico e Taranto durante il Quaternario. Geografia Fisica e Dinamica Quaternaria, 3, 3-15.

[54] Sabato, L., Longhitano, S.G., Gioia, D., Cilumbriello, A. and Spalluto, L. (2012) Sedimentological and Morpho-Evolution Maps of the "Bosco Pantano di Policoro" Coastal System (Gulf of Taranto, Southern Italy). Journal of Maps, 8, 304-311. http://dx.doi.org/10.1080/17445647.2012.722791

[55] Schiattarella, M., Giano, S.I., Longhitano, S.G. and Beneduce, P. (2010) La costa della Basilicata ionica. In: Ginesu, S., Ed., La costa d'Italia, Il Mar Ionio, Carlo Delfino Editore, Sassari, 249-268. 
[56] Mauro, A. (2004) La vulnerabilità dei sistemi costieri-il potenziale trasporto solido litoraneo in prossimità della foce del fiume Basento. In: Coste: Prevenire, Programmare, Pianificare, Collana Editoriale di Studi e Ricerche dell’AdB Basilicata, 29-44.

[57] Vita, M., Bulfaro, M., Cavuoti, C., Pagliaro, S., Biscione, A. and Valanzano, A. (2006) Evoluzione del litorale ionico lucano tra le foci dei fiumi Sinni e Bradano. Collana Editoriale di Studi e Ricerche dell'Autorità di Bacino della Basilicata.

[58] Sabato, L., Longhitano, S.G., Cilumbriello, A., Gioia, D. and Spalluto, L. (2010) Relazione sullo stato di avanzamento del progetto ProviDune (LIFE07NAT/IT/000519). Conservazione e ripristino di habitat dunali nei siti delle province di Cagliari, Matera e Caserta.

[59] Kulkarni, C.D., Levoy, F., Monfort, O. and Miles, J. (2004) Morphological Variations of a Mixed Sediment Beachface (Teignmouth, UK). Continental Shelf Research, 24, 1203-1218. http://dx.doi.org/10.1016/j.csr.2004.03.005

[60] Horn, D.P. and Walton, S.M. (2007) Spatial and Temporal Variations of Sediment Size on a Mixed Sand and Gravel Beach. Sedimentary Geology, 202, 509-528. http://dx.doi.org/10.1016/j.sedgeo.2007.03.023

[61] Bluck, B.J. (1967) Sedimentation of Beach Gravels: Examples from South Wales. Journal of Sedimentary Petrology, 37, 128-156.

[62] Orford, J.D. (1977) A Proposed Mechanism for Beach Sedimentation. Earth Surface Processes, 2, 381-400. http://dx.doi.org/10.1002/esp.3290020409

[63] Williams, T. and Caldwell, E. (1988) Particle Size and Shape in Pebble-Beach Sedimentation. Marine Geology, 82, 199-215. http://dx.doi.org/10.1016/0025-3227(88)90141-7

[64] Breil, M., Catenacci, M. and Travisi, C. (2007) Impatti del cambiamento climatico 530 sulle zone costiere: Quantificazione economica di impatti e di misure di adattamento-Sintesi di risultati e indicazioni metodologiche per la ricerca futura.

[65] Simeoni, F. (2007) L'esperienza del Progetto: Rischio per Erosione dei Litorali Italiani. Workshop “Cambiamenti climatici e rischio costiero", Palermo, 27-28 giugno 2007, 27-29.

[66] FEEM, ENEA (2003) La risposta al cambiamento climatico in Italia. Rapporto Enea—Ministero Ambiente e Territorio, Roma.

[67] Longhitano, S.G. and Colella, A. (2007) Geomorphology, Sedimentology and Recent Evolution of the Anthropogenically Modified Simeto River Delta System (Eastern Sicily, Italy). Sedimentary Geology, 194, 195-221. http://dx.doi.org/10.1016/j.sedgeo.2006.06.004

[68] Griggs, G.B. and Trenhaile, A.S. (1994) Coastal Cliffs and Platforms. In: Carter, R.W.G. and Woodroffe, C.D., Eds., Coastal Evolution: Late Quaternary Shoreline Morphodynamics, Cambridge University Press, Cambridge, 425-450.

[69] Spilotro, G., Di Bratto, M., Cecilia, G. and Leandro, G. (1998) Evoluzione recente del litorale alto Jonico compreso tra foce Sinni e foce Bradano. Atti del dipartimento di Strutture, Geotecnica e Geologia Applicata, Potenza, Università della Basilicata 1/98, 1-46.

[70] Spilotro, G., Canora, F., Caporale, F. and Leandro, G. (2004) Interventi nei bacini e dinamica delle coste. In: Processo di interrimento degli invasi: Genesi effetti ed interventi per la tutela dell'ambiente, Collana Editoriale di Studi e Ricerche dell’Autorità di Bacino della Basilicata, 239-270.

[71] Cocco, E., De Pippo, T., De Lauro, M. and Monda, C. (1988) Focus erosivi sul litorale metapontino (Golfo di Taranto). Memorie Società Geologica Italiana, 41, 703-709.

[72] Cooper, J.A.G., McKenna, D.W.T. and O’Connor, M. (2007) Mesoscale Coastal Behavior Related to Morphological Self-Adjustment. Geology, 35, 187-190. http://dx.doi.org/10.1130/G23016A.1

[73] Tanner, W.F. (1982) Equilibrium Shoreline. In: Schwartz, M.L., Ed., The Encyclopedia of Beaches and Coastal Environments, Hutchinson-Ross, Stroudsburg, 391-392.

[74] Dott, R.H. (1982) Episodic Sedimentation: How Normal Is Average? How Rare Is Rare? Does It Matter? Journal of Sedimentary Research, 53, 5-23. http://dx.doi.org/10.1306/212F8148-2B24-11D7-8648000102C1865D

[75] Dott, R.H. and Bourgeois, J. (1982) Hummocky Stratification: Significance of Its Variable Bedding Sequences. Geological Society of America Bulletin, 93, 663-680. http://dx.doi.org/10.1130/0016-7606(1982)93<663:HSSOIV>2.0.CO;2

[76] Niedoroda, A.W., Swift, D.J.P. and Thorne, J.A. (1989) Modeling Shelf Storm Beds: Controls of Bed Thickness and Bedding Sequence. In: Morton, R.A. and Nummedal, D., Eds., Shelf Sedimentation, Shelf Sequences and Related Hydrocarbon Accumulation, Proceedings of the Gulf Coast Section, SEPM 7th Annual Research Conference, Tulsa, 15-39.

[77] Storms, J.E.A., Weltje, G.J., Van Dijke, J.J., Geel, C.R. and Kroonenberg, S.B. (2002) Process-Response Modeling of Wave-Dominated Coastal Systems: Simulating Evolution and Stratigraphy on Geological Timescales. Journal of 
Sedimentary Research, 72, 226-239. http://dx.doi.org/10.1306/052501720226

[78] Storms, J.E.A. (2003) Event-Based Stratigraphic Simulation of Wave-Dominated Shallow-Marine Environments. Marine Geology, 199, 83-100. http://dx.doi.org/10.1016/S0025-3227(03)00144-0

[79] De Vroeg, J.H., Smith, E.S.P. and Bakker, W.T. (1988) Coastal Genesis. Proceedings of the 21st International Conference on Coastal Engineering, ASCE, New York, 2825-2839.

[80] Stive, M.J.F. and De Vriend, H.J. (1995) Modelling Shoreface Profile Evolution. Marine Geology, 126, $235-248$. http://dx.doi.org/10.1016/0025-3227(95)00080-I

[81] Neill, S.P., Elliott, A.J. and Hashemi, M.R. (2008) A Model of Inter-Annual Variability in Beach Levels. Continental Shelf Research, 28, 1769-1781. http://dx.doi.org/10.1016/j.csr.2008.04.004

[82] Pilkey, O.H., Young, R.S., Riggs, S.R., Sam Smith, A.W., Wu, H. and Pilkey, W.D. (1993) The Concept of Shoreface Profile of Equilibrium: A Critical Review. Journal of Coastal Research, 9, 255-278.

[83] Elliot, I.G. and Clarke, D.J. (1982) Seasonal and Biennial Fluctuation in Subaerial Beach Sediment Volume on Warilla Beach, New South Wales. Marine Geology, 48, 89-103. http://dx.doi.org/10.1016/0025-3227(82)90131-1

[84] Dubois, R.N. (1988) Seasonal Changes in Beach Topography and Beach Volume in Delaware. Marine Geology, 81, 79-96. http://dx.doi.org/10.1016/0025-3227(88)90019-9

[85] Dean, R.G. (1990) Equilibrium Beach Profile: Characteristics and Applications. Journal of Coastal Research, 7, 53-84.

[86] Hardisty, J. (1990) Beaches: Form and Processes. Unwin Hyman, London.

[87] Inman, D.L., Elwany, M.H.S. and Jenkins, S.A. (1993) Shorerise and Bar-Berm Profiles on Ocean Beaches. Journal of Geophysical Research, 98, 18181-18199. http://dx.doi.org/10.1029/93JC00996 
Scientific Research Publishing (SCIRP) is one of the largest Open Access journal publishers. It is currently publishing more than 200 open access, online, peer-reviewed journals covering a wide range of academic disciplines. SCIRP serves the worldwide academic communities and contributes to the progress and application of science with its publication.

Other selected journals from SCIRP are listed as below. Submit your manuscript to us via either submit@scirp.org or Online Submission Portal.
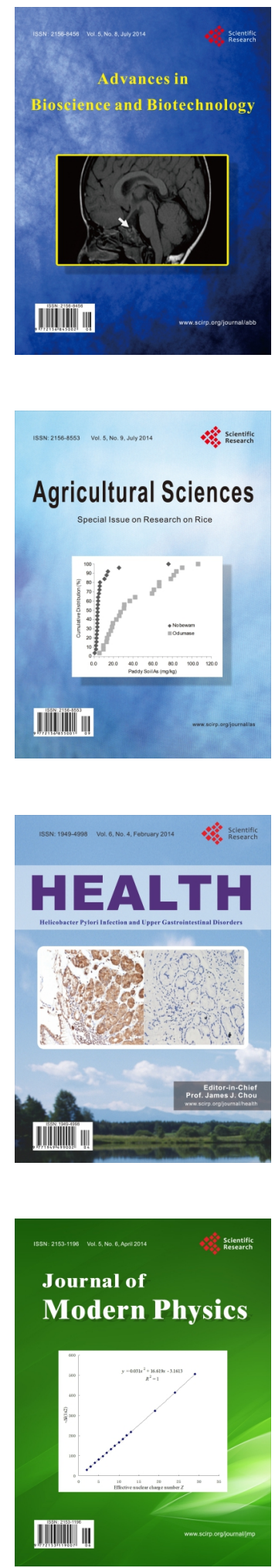
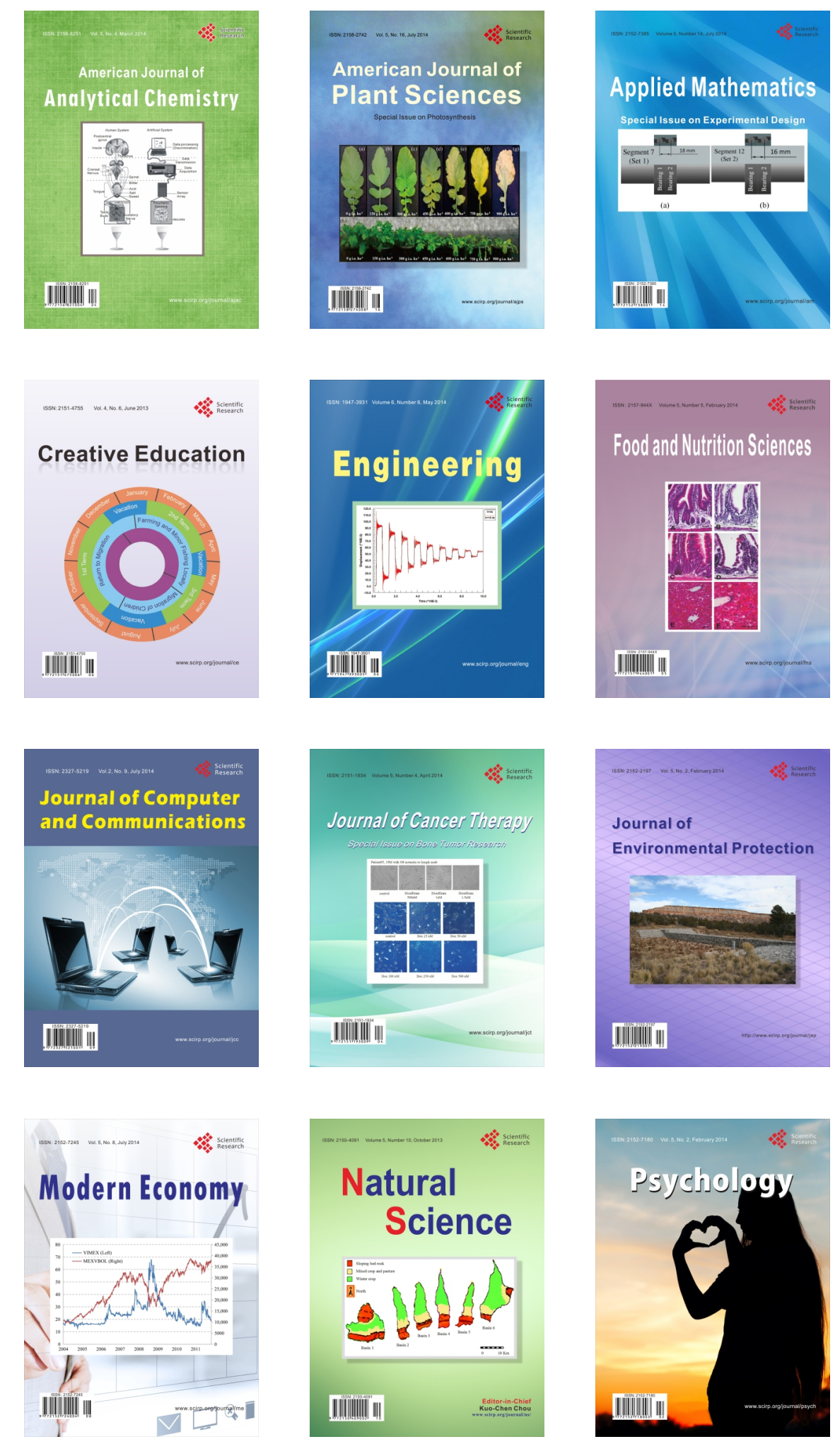